\title{
Multiple CsrA Proteins Control Key Virulence Traits in Pseudomonas syringae pv. tomato DC3000
}

\author{
María-Dolores Ferreiro, ${ }^{1}$ Joaquina Nogales, ${ }^{1}$ Gabriela A. Farias, ${ }^{1,2}$ Adela OImedilla, ${ }^{2}$ Juan Sanjuán, ${ }^{1}$ \\ and María Trinidad Gallegos ${ }^{1,+}$ \\ ${ }^{1}$ Department of Soil Microbiology and Symbiotic Systems, Estación Experimental del Zaidín (EEZ-CSIC), Granada, Spain; and \\ ${ }^{2}$ Department of Biochemistry, Cell and Molecular Biology of Plants, Estación Experimental del Zaidín (EEZ-CSIC), Granada, \\ Spain
}

Accepted 18 December 2017.

\begin{abstract}
The phytopathogenic bacterium Pseudomonas syringae pv. tomato DC3000 has a complex Gac-rsm global regulatory pathway that controls virulence, motility, production of secondary metabolites, carbon metabolism, and quorum sensing. However, despite the fact that components of this pathway are known, their physiological roles have not yet been established. Regarding the CsrA/RsmA type proteins, five paralogs, three of which are well conserved within the Pseudomonas genus (csrA1, csrA2, and $\operatorname{csr} A 3$ ), have been found in the DC3000 genome. To decipher their function, mutants lacking the three most conserved CsrA proteins have been constructed and their physiological outcomes examined. We show that they exert nonredundant functions and demonstrate that CsrA3 and, to a lesser extent, CsrA2 but not CsrA1 alter the expression of genes involved in a variety of pathways and systems important for motility, exopolysaccharide synthesis, growth, and virulence. Particularly, alginate synthesis, syringafactin production, and virulence are considerably de-repressed in a $\operatorname{csrA3}$ mutant, whereas growth in planta is impaired. We propose that the linkage of growth and symptom development is under the control of CsrA3, which functions as a pivotal regulator of the DC3000 life cycle, repressing virulence traits and promoting cell division in response to environmental cues.
\end{abstract}

Bacteria use a wide variety of mechanisms for sensing environmental changes and complex global regulatory networks to reprogram numerous cellular processes in response to physiological demands. Two-component systems (TCS) consisting of a membrane-bound histidine kinase, which senses a specific external signal, and a cytoplasmic response regulator, which mediates the cellular response, enable bacteria to detect external

Current address for Joaquina Nogales: Plant Biology Division, The Samuel Roberts Noble Foundation, Ardmore, OK 73401, U.S.A.

${ }^{\dagger}$ Corresponding author: María-Trinidad Gallegos;

E-mail: maritrini.gallegos@eez.csic.es

Funding: This research was supported by grant BIO2014-55075-P from the Spanish Ministry of Economy, Industry and Competitiveness cofinanced by the European Regional Development Fund, a FPU contract from the Spanish Ministry of Education, Culture and Sports (FPU14/02120), and a Ciência sem Fronteiras fellowship (BEX10043/13-6, CAPES-Brazil).

*The $\boldsymbol{e}$-Xtra logo stands for "electronic extra" and indicates that seven supplementary figures and three supplementary tables are published online.

(c) 2018 The American Phytopathological Society stimuli and generate a response that allows adaptation through changes in gene expression. The TCS GacS/GacA, present in numerous gram-negative bacteria, controls pathogenicity, plant growth promotion, survival, motility, biofilm formation, or production of secondary metabolites, such as antibiotics, quorumsensing signals, toxins, siderophores, extracellular polysaccharides, and secreted proteins (Heeb and Haas 2001; Hrabak and Willis 1992; Lapouge et al. 2008; Laville et al. 1992; Sonnleitner et al. 2009). The GacS/GacA is a particular TCS because it acts posttranscriptionally through the RNA regulatory pathway of secondary metabolism Rsm (Brencic et al. 2009; Cha et al. 2012; Heeb et al. 2002). This signal transduction cascade is very well-known in Pseudomonas fluorescens $\mathrm{CHA} 0$ and starts with the reception of one or more signals by the membrane sensor GacS, which phosphorylates itself and the cytoplasmic GacA. Phosphorylated GacA binds to a conserved sequence called the Gac box in the promoters of some small regulatory RNAs ( $r \sin X, r \operatorname{sm} Y$, and $r \operatorname{sm} Z$ ), inducing their expression. Those RNAs exhibit high affinity for two small RNA-binding proteins, RsmA and RsmE (Heeb et al. 2002; Humair et al. 2010; Kay et al. 2005; Kulkarni et al. 2006; Valverde et al. 2003). RsmA and RsmE proteins bind to certain mRNAs usually blocking their Shine-Dalgarno (SD) sequences, thereby affecting their stability, turnover and/or translation rates (Blumer et al. 1999; Reimmann et al. 2005; Schubert et al. 2007; Valverde and Haas 2008). The rsm RNAs antagonize RsmA and RsmE binding to mRNAs in a competitive manner; they contain multiple binding sites that sequester and store RsmA and RsmE, acting as 'protein sponges' (Blumer et al. 1999; Duss et al. 2014; Reimmann et al. 2005). RsmA and RsmE belong to the CsrA/RsmA family of small RNA-binding proteins that posttranscriptionally regulate protein synthesis. CsrA (carbon storage regulator) was first described in Escherichia coli, in which it plays a major role in controlling the intracellular carbon flux (Romeo et al. 1993). Subsequently, CsrA homologs were found in many $\gamma$-proteobacteria, in which they were sometimes called RsmA (repressor of secondary metabolism), as in Pseudomonas aeruginosa (Pessi et al. 2001). Initially, binding to sites overlapping the $\mathrm{SD}$ sequences on target mRNAs to prevent translation initiation was believed their only mode of action, but new ways of repression and even activation of transcription and translation have been recently reported (Vakulskas et al. 2015).

Pseudomonas syringae pv. tomato DC3000 causes bacterial speck on tomato thanks to its large repertoire of effectors that are secreted through the type III secretion system and the phytotoxin coronatine, which disrupts signaling mediated by jasmonic acid and stimulates stomatal opening, allowing the 
entry of bacteria to the apoplast. In addition, $P$. syringae pv. tomato possesses other tools that contribute to pathogenicity, such as flagella and biosurfactants, which facilitate its movement, or exopolysaccharides that prevent desiccation. DC3000 produces several polar flagella (Roine et al. 1997; Vargas et al. 2013) and six lipopeptides with biosurfactant activity, i.e., syringafactins $\mathrm{A}$ to $\mathrm{F}$, which are synthesized by a nonribosomal peptide synthetase encoded by two genes, syfA and $\operatorname{syfB}$ (Berti et al. 2007). DC3000 displays different types of motility. Swimming is the predominant movement in liquid or viscous media and requires the presence of flagella, whereas the syringafactin is dispensable. In contrast, both flagella and syringafactin are required for swarming, a rapid and coordinated movement of the bacterial population over solid or semisolid surfaces (Berti et al. 2007; Burch et al. 2010, 2012; Nogales et al. 2015).

In DC3000 the GacS/GacA TCS activates transcription of several small regulatory RNAs and genes encoding alternative sigma factors (Chatterjee et al. 2003; Vargas et al. 2013). Bioinformatic studies revealed that DC3000 possesses seven putative small rsm RNAs (rsmX1 to $r s m X 5$, rsmY, rsmZ), of which $r \operatorname{sim} Y$ and, partially, $r \operatorname{sim} Z$ have been shown to be controlled by GacA (Chatterjee et al. 2003; Moll et al. 2010; Vargas et al. 2013; Valverde et al. 2003). In addition, four genes encoding CsrA proteins are annotated in its genome (Kulkarni et al. 2006; Lapouge et al. 2008; Moll et al. 2010; Valverde et al. 2003). So far, the GacA has been shown to control carbon metabolism, virulence, motility, production of secondary metabolites, and quorum sensing in DC3000 (Chatterjee et al. 2003; Vargas et al. 2013). Since the components of the Gac-rsm pathway are known but their physiological roles have not been yet established, the aim of this work was to link specific CsrA alleles to phenotypes known to be GacA regulated.

\section{RESULTS}

\section{CsrA proteins in Pseudomonas spp.}

Apart from the four genes encoding CsrA proteins that were annotated in the DC3000 chromosome (PSPTO_1629 [csrAl], PSPTO_1844 [csrA2], PSPTO_3566 [csrA3], and PSPTO_3943 [which we called $c s r A 4$ ]), we have found another one, PSPTO_ 5621, now named csrA5. csrA2 and $\operatorname{csr} 33$ (189 bp), csrAl and csrA4 (195 bp), and $\operatorname{csr} A 5$ (225 bp) encode very similar proteins of 62, 64, and 74 amino acids, respectively. The alignment of the five sequences shows that CsrA2 and CsrA3 exhibit the highest percentage of identity at both DNA $(64 \%)$ and protein $(71 \%)$ levels (Fig. 1), and they are also present in most $P$. syringae pathovars, in which they are $100 \%$ identical. CsrA5 is the most distinct paralog in size and sequence, with an identity below $51 \%$ when compared with the rest of CsrA proteins (Fig. 1). Specifically, the amino acids involved in RNA binding (Schubert et al. 2007) are more conserved in CsrA1, CsrA2, and CsrA3 than in CsrA4 or CsrA5.

Considering the multiple CsrA variants found in DC3000, the question arose as to whether this occurred in other Pseudomonas strains. We searched the databases for the different CsrA/RsmA orthologs within the Pseudomonas genus and proteins from 250 fully sequenced strains were compared (Supplementary Table S1). Also, a phylogenetic tree, with CsrA proteins from 73 representative Pseudomonas strains, using the E. coli CsrA as outgroup, allowed the distinction of several CsrA variants (Supplementary Fig. S1). CsrA2/RsmA was the most conserved protein, with high homology to E. coli and other $\gamma$-proteobacteria CsrAs (Heeb et al. 2006; Vakulskas et al. 2015). CsrA3/RsmE proteins are exclusive of the P. fluorescens lineage, in which they are conserved within the groups. CsrA1/RsmI is also present throughout the $P$. fluorescens lineage except in the $P$. protegens group, which only carries CsrA3/RsmE together with CsrA2/RsmA. CsrA4 and CsrA5, only present in the $P$. syringae group, and RsmN/F, specific of P. aeruginosa (Marden et al. 2013; Morris et al. 2013), are the most divergent with respect to CsrA2. Moreover, there are several CsrA variants present in particular strains that do not group with any of the aforementioned, due to either their different sizes, varied sequences, or both. These data are summarized in Table 1.

\section{Effect of $\operatorname{csr} A$ deletions on DC3000 growth in culture.}

In previous transcriptomic experiments, we observed that $\operatorname{csr} A 2$ and $\operatorname{csr} A 3$ mRNA levels were the highest, $\operatorname{csr} A 5$ were measurable but much lower and $\operatorname{csrAl}$ and $\operatorname{csrA} 4$ mRNAs were undetectable, both in swarming and MMR (mannitol/glutamate minimal medium) liquid culture (Nogales et al. 2015). This, together with the fact that CsrA1, CsrA2, and CsrA3 were the most conserved proteins in Pseudomonas spp., prompted us to begin studying $\Delta c s r A 1, \Delta c s r A 2$, and $\Delta c s r A 3$ mutants lacking those alleles. First, we assessed the growth of the three mutant strains in Luria-Bertani (LB), MMR, and MMF (minimal medium simulating the plant apoplast composition) at 20 and $28^{\circ} \mathrm{C}$, observing that the growth rate of the mutants was similar to that of the wild type in most of the media and temperatures. Only in MMF at $20^{\circ} \mathrm{C}, \Delta \operatorname{csr} A 2$ and, more pronounced, $\Delta \operatorname{csr} A 3$ were delayed compared with the wild type, and in trans expression of the corresponding alleles complemented growth in those conditions (Supplementary Fig. S2).

\section{Alginate production and \\ alginate biosynthesis gene expression.}

We observed that the $\Delta \operatorname{csr} A 3$ mutant was considerably more mucoid than the wild type when it was grown on LB plates at $28^{\circ} \mathrm{C}$. Thinking that the mucus could be alginate, we measured its production and observed that, in those conditions, $\Delta \operatorname{csr} A 3$

\footnotetext{
PfI CHAO RSmE MLILTRKVGESINIGD-DITITILGVSG--QQVRIGINAPKDVAVHREEIYQRIQAGLTAPDKRETP

Pae PA01 RsmA MLILTRRVGETLMVGD-DVTVTVLGVKG--NQVRIGVNAPKEVAVHREEIYQRIQKEKDQEPNH

ECO CSRA MLILTRRVGETLMIGD-EVTVTVLGVKG--NQVRIGVNAPKEVSVHREEIYQRIQAEKSQQSSY

Pto DC3000 CSrA2 MLILTRRCAESLIIGDGEITVTVLGVKG--NQVRIGVNAPKEVAVHREEIYLRIKKE--KDEEPSH-1- - - 100\%

CSrA3 MLILTRKVGESINIGD-EITVTILGVQG--LQVRLGINAPKNVSVHREEIYKRIQAELAPNQDPQ- - - - - - - 64\%

CSRA1 MLVLTRDIGETFSIGD-DITVQILGVNG - -NQVRLGISAPKDIKVHRAEVYKRIANKLSQQAAQTQP - - - - - - - 64\%

CSRA4 MLCLTRRFGESIIIGN-DIKITVISGRD--GQIRLGIDAPÁGLAVDRSEIRTAKLANPRNGSERHVG- - - - - - 55\%

CSrA5 MLLLTRREGENIVIGD-GIQIQVLSVSEDTGDVRIQIEAPDVVEAQQGRTAGGNEVTDH-KPGPVITHKRRWRSLVTQ $49 \%$
}

Fig. 1. Multiple sequence alignment of all the CsrA paralogs found in Pseudomonas syringae pv. tomato DC3000. The percentage of identity with respect to CsrA2 is shown. RsmE (PFLCHA0_c21410) from P. protegens CHA0, RsmA (PA0905) from P. aeruginosa PAO1, and CsrA from Escherichia coli (b2696) are also included, with the residues important for RNA binding shown in gray (Gutiérrez et al. 2005; Mercante et al. 2006; Schubert et al. 2007). The nonconserved residues are underlined. 
significantly synthesized more alginate than all the other strains (Fig. 2A). DC3000 alginate production is very low compared with other Pseudomonas spp., regardless of the culture medium and temperature (Pérez-Mendoza et al. 2014; Prada-Ramírez et al. 2016). In minimal medium at $20^{\circ} \mathrm{C}$, the optimal conditions for the wild type, the results were similar; $\triangle \operatorname{csr} A l$ and $\triangle \operatorname{csr} A 2$ behaved like the wild type and the $\triangle \operatorname{csr} A 3$ mutant overproduced alginate (Supplementary Fig. S3). The exopolysaccharide (EPS) produced by $\triangle c s r A 3$ was, in fact, alginate, given that the double alg8/csrA3 mutant, which lacks a glycosyltransferase involved in alginate biosynthesis (Alg8), is unable to produce it and has lost the mucoid aspect.

Consistent with alginate production, relative mRNA levels of $\operatorname{alg} D$ (first gene of the alginate biosynthesis operon) in the $\triangle \operatorname{csr} A 3$ mutant was eightfold higher than in the wild type. Overexpression of $c s r A 3$ in the mutant reduced fourfold $\operatorname{alg} D$ mRNA levels compared with the wild type and 28 -fold compared with $\Delta \operatorname{csr} A 3$ (Fig. 2B), suggesting that CsrA3 is a negative regulator of $\operatorname{alg} D$ gene expression.

\section{Motility.}

Since the Gac-rsm pathway regulates motility in DC3000 (Chatterjee et al. 2003; Vargas et al. 2013) and other Pseudomonas spp. (Burrowes et al. 2006; Heurlier et al. 2004; Kay et al. 2006; Martínez-Granero et al. 2012; Navazo et al. 2009), swimming and swarming motility assays were carried out with gacA and $\Delta c s r A$ mutants to establish whether the CsrA regulators contributed to that phenotype. The swimming of the three $\Delta$ csrA mutants was similar to that of the wild type but clearly distinct from the gacA mutant (Fig. 3A). However, overexpression of $c s r A 2$ and $\operatorname{csrA} 3$ in their respective mutants slightly reduced this movement, whereas the $\Delta$ csrAl mutant remained the same (Fig. 3A). Regarding swarming motility, the behavior was different among the $\Delta c s r A$ mutants: $\Delta c s r A l$ was indistinguishable from the wild type, but the surface movement of $\Delta c s r A 2$ and $\Delta c s r A 3$ was significantly faster than that of the parental strain, with $\triangle c s r A 3$ being the best swarmer (Fig. 3B). Conversely, gacA cells remained at the site of inoculation. This negative effect of CsrA2 and CsrA 3 on motility was confirmed by overexpressing the corresponding alleles in a plasmid, which inhibited swarming at different degrees (Fig. 3B).

Given that the $\Delta \operatorname{csr} A 3$ mutant produced significantly more alginate than the other strains, we hypothesized that this EPS could be facilitating $\Delta c s r A 3$ swarming. However, the $\operatorname{csr} A 3 /$ alg 8 double mutant spread on PG-agar (0.5\% protease peptone No. 3 [Difco] and $0.2 \%$ glucose with $0.5 \%$ Difco bacto agar) plates similarly to $\Delta \operatorname{csr} A 3$ (Supplementary Fig. S4); therefore, the increased alginate production is not responsible for the faster swarming motility exhibited by this mutant. Consequently, we analyzed other features influencing this phenotype, like flagella synthesis and biosurfactant production.

\section{Flagella synthesis and gene expression.}

Flagella are essential for DC3000 swimming and swarming movements (Vargas et al. 2013; Nogales et al. 2015), and the increased motility of the $\Delta c s r A 2$ and $\triangle \operatorname{csr} A 3$ mutants suggested that those proteins could be functioning as negative regulators of flagellar biogenesis. To verify whether CsrA proteins regulated flagellin production, $\mathrm{fliC}$ expression was measured, in DC3000, gacA, the $\Delta c s r A$ mutants, and the complemented strains, by $\beta$-galactosidase assays using a translational fusion. fliC expression in the $\Delta c s r A$ and gacA mutants were similar to those in the wild type, and gene complementation did not have a significant effect in any of the $\Delta \operatorname{csr} A$ mutants (Fig. 4A). Furthermore, $\triangle \operatorname{csr} A 1, \Delta \operatorname{csr} A 2$, and $\triangle \operatorname{csr} A 3$ were indistinguishable from the wild type regarding their flagellar morphology and number, as were the complemented strains (Fig. 4B; Supplementary Fig. S5). Therefore, CsrA1, CsrA2, and CsrA 3 do not control flagella production in DC3000, at least under swarming conditions.

Observing the swarmer cells by transmission electron microscopy (TEM), we noticed that those of the $\Delta$ csrA3-complemented strain were short and coccoid-shaped differently from the wild type and the $\Delta c s r A 3$ mutant. This change in morphology was also perceived in fresh samples from the auto-agglutination assays (discussed below), and it is most probably related to the higher growth rate of this strain.

\section{Syringafactin production and gene expression.}

Given that $\triangle c s r A 2$ and $\triangle c s r A 3$ increased swarming was not due to altered flagella synthesis or assembly, we hypothesized that it could be attributable to an increase in biosurfactant production, as it had been previously demonstrated for a fle $Q$ mutant (Nogales et al. 2015). To check this possibility, we assessed syringafactin production, observing that the surfactant halo generated by the $\Delta \operatorname{csr} A 3$ mutant was three to four times bigger than that of the wild-type strain or the $\Delta$ csrAl mutant (Fig. 5A). Also, a $c s r A 3 / s y f A$ double mutant did not produce syringafactin and was not able to move on PG-agar plates, although its swimming motility was similar to that of the wild type. Therefore, the higher production of syringafactin by the $\Delta$ csrA3 mutant seems to be the cause of its greater swarming motility. The $\Delta \operatorname{csr} A 2$ mutant exhibited an intermediate behavior, with a syringafactin halo 1.4- to 1.7-fold bigger than the wild type. Overexpression of $\operatorname{csr} A 2$ and $\operatorname{csr} A 3$ in their respective mutants caused partial and total inhibition of the biosurfactant production, suggesting that CsrA2 and, more efficiently, CsrA3 negatively regulate this process in DC3000. The latter behavior is similar to that observed with the gacA mutant, which did not produce syringafactin (Fig. 5A).

To elucidate the mechanisms regulating syringafactin production, syfA expression was quantified by quantitative reverse transcription-polymerase chain reaction (qRT-PCR) (Fig. 5B).

Table 1. Presence of different CsrA variants in the Pseudomonas genus ${ }^{\mathrm{a}}$

\begin{tabular}{|c|c|c|c|c|c|c|c|}
\hline Lineage & CsrA1 & CsrA2 & CsrA3 & CsrA4 & CsrA5 & RsmF & Others $^{b}$ \\
\hline \multicolumn{8}{|l|}{ P. fluorescens lineage } \\
\hline P. fluorescens group & 78 & 100 & $100 *$ & & & & $5^{*}$ \\
\hline P. syringae group & 100 & 100 & 100 & 10 & $58 *$ & & 5 \\
\hline$P$. putida group & 97 & 100 & 97 & & & & 26 \\
\hline P. protegens group & & 100 & 100 & & & & \\
\hline \multicolumn{8}{|l|}{ P. aeruginosa lineage } \\
\hline P. aeruginosa group & & 100 & & & & 96 & 34 \\
\hline P. oleovorans group & & 100 & & & & & 14 \\
\hline P. stutzeri group & & 100 & & & & & \\
\hline
\end{tabular}


syfA mRNA levels in $\triangle c s r A l$ were similar to those in the wild type, increased twofold in $\triangle \operatorname{csr} A 2$ and fourfold in $\triangle \operatorname{csr} A 3$, and were negligible in the gacA mutant. In trans gene expression diminished syfA mRNA levels eightfold with $\operatorname{csr} A 3$ and to the wild-type levels with $c s r A 2$. Next, we measured syfA expression using a translational fusion to ' $l a c Z$ (Fig. 5D), observing that the lack of $c s r A 2$ and $c s r A 3$ caused a significant increase in $\beta$-galactosidase activity (three- and fivefold, respectively), with respect to the wild type, but in trans gene expression dramatically repressed it (11-fold with $c s r A 2$ and 16-fold with $c s r A 3)$. Expression of syfA in the gacA mutant was also diminished 50fold with respect to the wild type, whereas the lack of $\operatorname{csr} A 1$ or its overexpression did not have any effect. In summary, these results are in agreement with that observed in syringafactin production and confirm that CsrA3 and, to a lesser extent CsrA2, are involved in its regulation. However, this negative regulation could be exerted directly on $s y f A$ or indirectly through SyfR, the LuxR-like transcriptional activator of the $s y f A B C D$ operon (Berti et al. 2007; Nogales et al. 2015). For that reason, we analyzed $s y f R$ expression by qRT-PCR and $\beta$-galactosidase assays, obtaining a similar pattern (Fig. $5 \mathrm{C}$ and $\mathrm{E}$ ). Therefore, CsrA3 and, to a lesser degree, CsrA2 probably inhibit SyfR translation, which in turn prevents activation of the syringafactin biosynthetic pathway.

\section{Virulence.}

To study the impact of CsrA1, CsrA2, and CsrA3 on DC3000 virulence, we carried out infection assays in tomato plants, comparing the abilities of the wild type and the mutants to multiply in tomato leaf tissues by monitoring bacterial populations and development of disease symptoms for 10 days after inoculation by spray (Fig. 6A to C). All the mutants entered the tomato leaves and grew in the apoplast, in which their populations reached a maximum at 3 days postinoculation (dpi). However, $\triangle c s r A 2$ and $\triangle \operatorname{csr} A 3$ behaved differently from the wild type and $\Delta \operatorname{csr} A 1 . \Delta \operatorname{csr} A 2$ initially grew like the wild type but, at $6 \mathrm{dpi}$, its population had decreased drastically, and $\Delta c \operatorname{cs} A 3$ did not multiply as the others, so its populations were the lowest throughout the assay (Fig. 6A). The disease symptoms caused by the wild type and all the assayed mutants were similar, small water-soaked lesions that appeared 2 to 3 days after inoculation and soon turned brown, with the surrounding tissue turning yellow (Fig. 6C). The
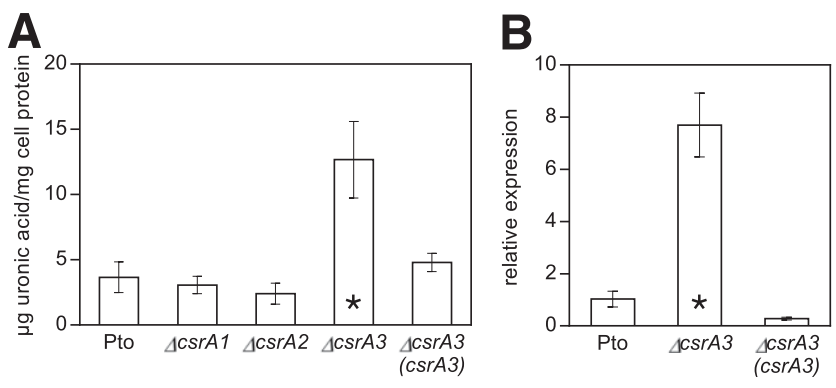

Fig. 2. CsrA3 inhibits alginate production in Pseudomonas syringae pv. tomato DC3000. A, DC3000, $\Delta \operatorname{csr} A 1, \Delta \operatorname{csr} A 2$, and $\Delta \operatorname{csr} A 3$ were grown on Luria-Bertani (LB) plates for 2 days at $28^{\circ} \mathrm{C}$, and the uronic acids produced by the different strains were measured. The complemented $\Delta c s r A 3$ strain is also shown for comparison. Values are the means of four independent replicates and error bars correspond to the standard deviation. B, Expression analysis of algD in DC3000 and the $\Delta \operatorname{csr} A 3$ mutant by quantitative reverse transcription-polymerase chain reaction. Total RNAs were obtained from bacteria grown in LB plates at $28^{\circ} \mathrm{C}$ for 2 days. Expression values were normalized with the housekeeping gene gyrA and referred to the wildtype condition. The graph shows the average mRNA levels, and error bars correspond to the standard deviation of three biological replicates. An asterisk $\left(^{*}\right)$ indicates that only the difference between $\Delta \operatorname{csr} A 3$ and the rest of the strains were significant, as determined by one-way analysis of variance $(P<0.01)$. severity of the symptoms caused by all the $\Delta \operatorname{csr} A$ mutants was quantified as the extension of the necrotic areas, with results similar to that of the wild type (around 6\%). These results show that the loss of CsrA1 does not modify plant growth or virulence; however, the loss of CsrA2 and, more significantly, CsrA3 have an effect on internal leaf colonization but not on symptoms. That is, those strains appear to be more virulent than the wild type despite exhibiting a reduced growth rate in plant. To verify this, the complemented $\Delta \operatorname{csr} A 3$ mutant was assayed, observing that the growth in the plant was restored, whereas the symptoms were milder and only small halos of chlorosis without necrosis were distinguished (Fig. 6B and C). Hence, CsrA1, CsrA2, and CsrA3 do not seem to be required for DC3000 pathogenicity under the tested conditions. On the contrary, CsrA3 may be limiting the expression of some virulence factors.

It was previously observed that DC3000 elicited a hypersensitive response (HR) in tobacco (Nicotiana tabacum) whereas the gacA mutant failed (Chatterjee et al. 2003). Here, we show that the same occurs in bean (Phaseolus vulgaris cv. Canadian Wonder): P. syringae pv. tomato DC3000 elicited typical HR when infiltrated with $10^{7} \mathrm{CFU}$ per milliliter, but the HR symptoms caused by the gacA mutant were significantly reduced (Fig. 6D). Other mutants, such as $c o r S$, which does not synthesize coronatine, $h r p L$, which neither produces a type 3 secretion system (T3SS) nor coronatine, or $\Delta h r c Q_{b^{-}} U$, which lacks a functional T3SS but it is able to produce coronatine, were assayed to check their abilities to elicit HR (Fig. 6D). Only the mutants lacking the T3SS ( $h r p L$ and $\Delta h r c Q_{b}-U$ ) did not elicit HR, even when they were able to produce coronatine $\left(\Delta h r c Q_{b^{-}} U\right)$. On the contrary, a mutant unable to produce coronatine but with a functional T3SS (corS) caused a HR like the wild type. This agrees with an earlier proposal that the requirement for HR elicitation is a functional T3SS (Collmer et al. 2000). To determine whether the phenotype observed with the gacA mutant was mediated by the CsrA proteins, we analyzed the lesions caused by the $\triangle \operatorname{csr} A 2$ and $\triangle \operatorname{csr} A 3$ mutants and their complemented strains in bean leaves. $\Delta c s r A 2$, its complemented strain and $\Delta c s r A 3$ caused a HR indistinguishable to that of the wild type. However, HR caused by $\Delta c s r A 3$ harboring pBBR1-MCS5::csrA3 was noticeably reduced (Fig. 6D).

Everything considered, the $\Delta c s r A 3$ mutant is impaired in apoplast colonization but not on virulence or HR elicitation. On the contrary, growth in planta was recovered in the complemented strain, but virulence and HR symptoms were significantly reduced. Consequently, CsrA3 may be inhibiting either T3SS expression, effector export to the plant cells, or both, both in compatible and incompatible infections. Consistent with this, relative mRNA levels of $h r p L$ and $h r p A$ in the $\Delta \operatorname{csr} A 3$ mutant under inducing conditions were 3.6 and 2.5 times higher, respectively, than in the wild type, whereas overexpression of $\operatorname{csr} 33$ in the mutant reduced them 1.4- and 3.0-fold (Fig. 6E). However, in the $\Delta c s r A 2$ mutant, $h r p L$ and hrpA levels were 1.4- and 1.9-fold higher than in the wild type and overexpression of csrA2 reduced them 2.2-fold (Supplementary Fig. S6). The expression and assembly of a functional T3SS apparatus in MMF cause auto-agglutination in P. syringae (Ortiz-Martín et al. 2010; Taira et al. 1999). We observed large bacterial aggregates with the wild-type strain that were absent in the $\Delta h r c Q_{b}-U$ preparations (Fig. 6F). The csrA3 mutant produced more numerous aggregates, significantly larger in size and more solid than those of the wild type, whereas those of the complemented strain were smaller and less dense (Fig. 6F). Consistent with hrpL and hrpA expression, the effect of CsrA2 on auto-agglutination was subtler. In conclusion, all these results suggest that CsrA3 has a major role repressing the expression and assembly of a functional T3SS in DC3000. 


\section{DISCUSSION}

To characterize the Gac-rsm system in P. syringae pv. tomato DC3000, we first identified the genes encoding its components. Seven rsm regulatory RNAs had been previously reported: rsmX1 to $r \operatorname{sm} X 5$, rsmY, and $r \operatorname{smZ}$ (Chatterjee et al. 2003; Moll et al. 2010; Valverde et al. 2003; Vargas et al. 2013). This is an exceptionally high number, only surpassed by Azotobacter vinelandii, which has eight (Hernández-Eligio et al. 2012; Manzo et al. 2011). Bacteria with csrA usually have between two and three paralogs (Kay et al. 2005, 2006; Lenz et al. 2005). Regarding the CsrA type proteins, in addition to the
A
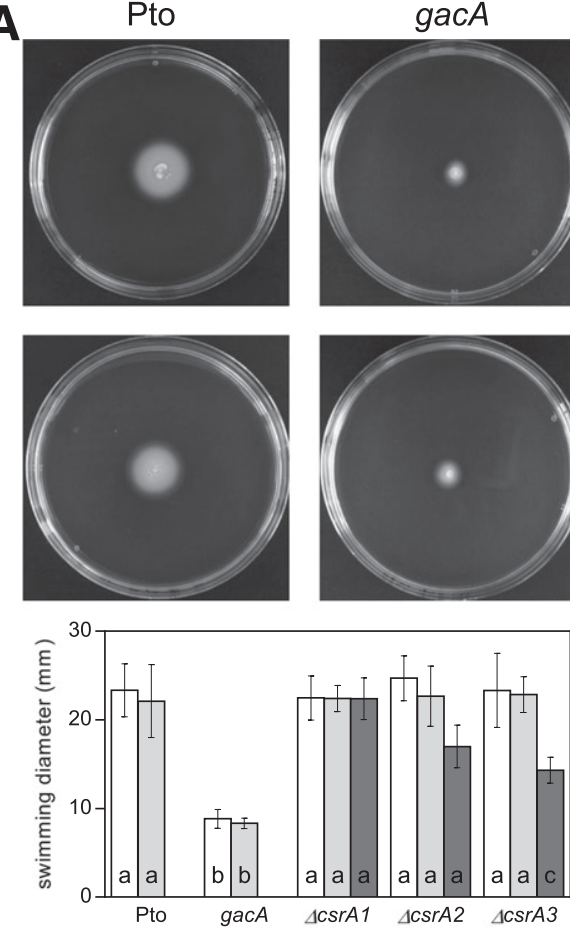

B
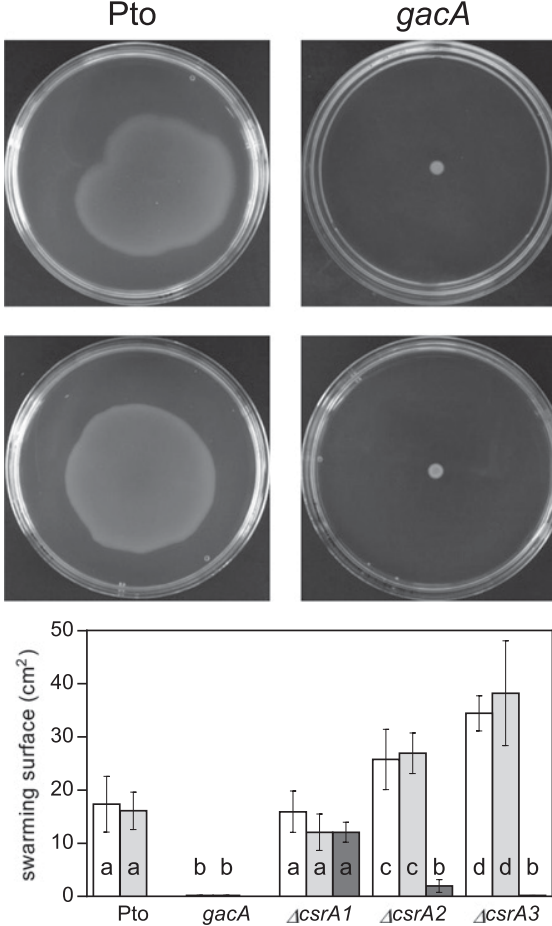

$\triangle c s r A 1$
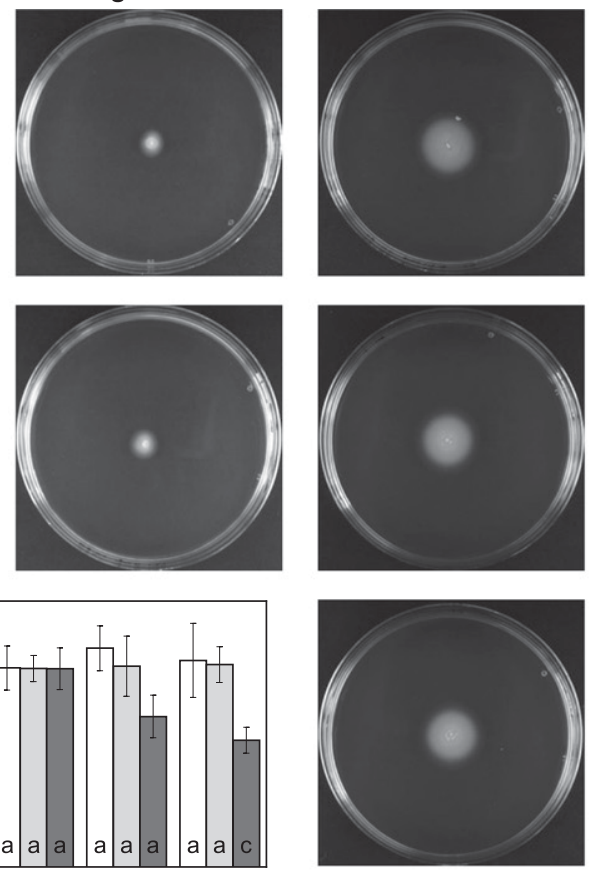

$\triangle c s r A 1$
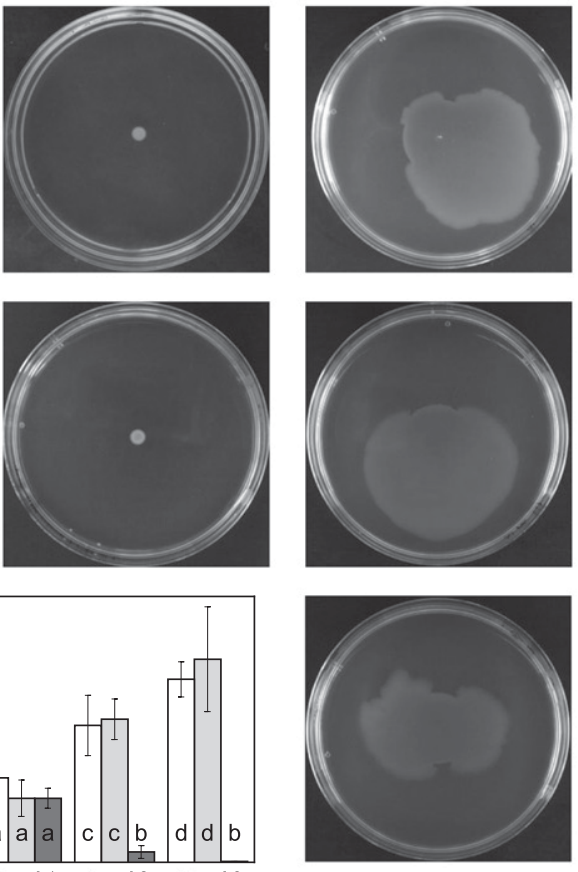

$\triangle c s r A 2$
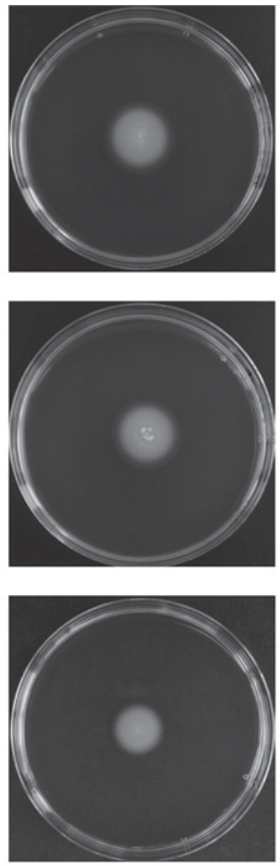

$\triangle c s r A 2$
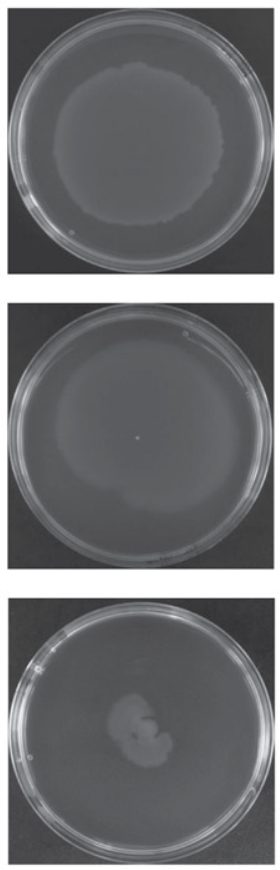
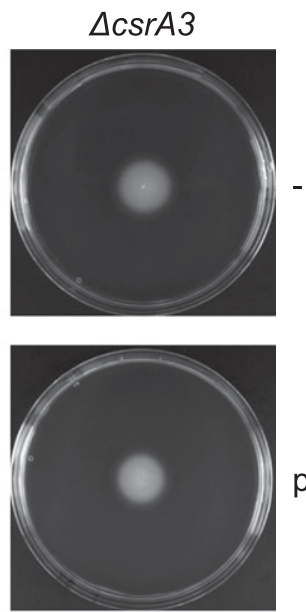

pBBR1-MCS5

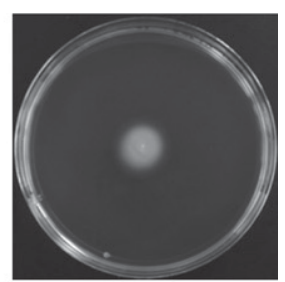

pBBR::csrA*

Fig. 3. CsrA2 and CsrA3 inhibit motility in Pseudomonas syringae pv, tomato DC3000. A, Swimming assays. The indicated strains were punctured in the center of Luria-Bertani $\left(0.3 \%\right.$ agar) plates and were incubated $48 \mathrm{~h}$ at $20^{\circ} \mathrm{C}$, when pictures were taken and swimming halos were measured. The graph shows the average diameter of the halos produced by strains without plasmid (white), with pBBR1-MCS5 (light gray), and complemented with $c s r A 1, c s r A 2$, or $c s r A 3$ cloned into pBBR1-MCS5 (dark gray). Error bars correspond to the standard deviation of three biological replicates; letters a to c denote analysis of variance (ANOVA) categories with significant differences $(P<0.01)$. B, Swarming assays. Bacterial suspensions of the indicated strains were deposited on the surface of peptone-glucose agar $(0.5 \%$ agar $)$ plates and were incubated $24 \mathrm{~h}$ at $20^{\circ} \mathrm{C}$. The graph shows the average swarming surface and error bars correspond to the standard deviation of three biological replicates; letters a to d denote ANOVA categories with significant differences $(P<0.01)$. 
four genes that were annotated in the DC3000 genome, we have identified a fifth one, PSPTO 5621 (Kulkarni et al. 2006; Lapouge et al. 2008; Moll et al. 2010; Valverde et al. 2003). When we compared DC3000 CsrA1 to CsrA5 with the orthologs present in the 250 fully sequenced Pseudomonas strains, we observed that CsrA3 orthologs are present in plant-associated and environmental bacteria belonging to the $P$. fluorescens lineage (Table 1). CsrA1-like proteins are present in the $P$. fluorescens lineage, except in the $P$. protegens group, but their sequences are substantially more diverse than those of CsrA2 or CsrA3. CsrA4 and CsrA5 only appear in the $P$. syringae group (taxid: 136849). CsrA2/RsmA is the most similar to $E$. coli and other $\gamma$-proteobacteria CsrA (Heeb et al. 2006; Vakulskas et al. 2015), and therefore, we propose it as the ancestral protein from which the other CsrA variants derived. In any case, the analysis of the multiple Pseudomonas CsrA/RsmA proteins demonstrates once again their exceptionally broad gene pool and genome plasticity (Rumbaugh 2014).

To start with the study of the complex Gac-rsm system in DC3000, we examined the physiological consequences of deleting the three most conserved CsrA proteins in Pseudomonas spp., namely, CsrA1, CsrA2, and CsrA3. Regarding alginate production in DC3000, the results presented here, together with the presence of a putative CsrA binding site (AGGA [Supplementary Fig. S7]) within the $\operatorname{algD} \mathrm{SD}$ region (Kulkarni et al. 2006, 2014), strongly suggest that the Gac-Rsm system posttranscriptionally regulates algD via CsrA3. In Azotobacter vinelandii as well as various Pseudomonas species, disruption of the GacS/GacA TCS also leads to reduction in alginate production or $\operatorname{alg} D$ expression (Lalaouna et al. 2012; Liao et al. 1994; Manzo et al. 2011; Willis et al. 2001). On the contrary, $\operatorname{alg} D$ and $\operatorname{alg} 8$ were upregulated in a $P$. aeruginosa rsmA mutant (Burrowes et al. 2006). Furthermore, RsmA binds to the $5^{\prime}$ leader of the $\operatorname{alg} D$ mRNA and represses translation in A. vinelandii (Manzo et al. 2011). Similarly, DC3000 CsrA3 probably binds to the $\operatorname{alg} D$ mRNA, acting as

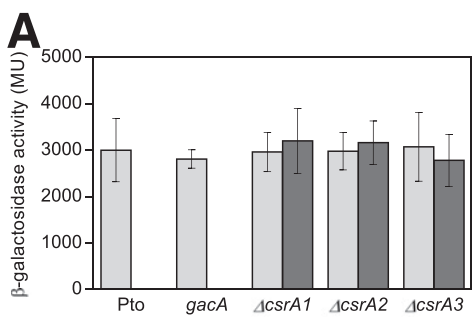

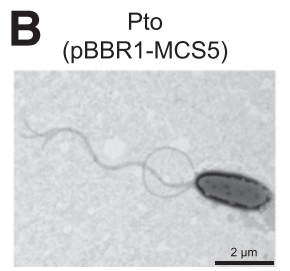

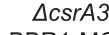
(pBBR1-MCS5)

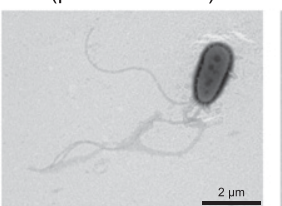

$\triangle c s r A 3$ (pBBR::csrA3)

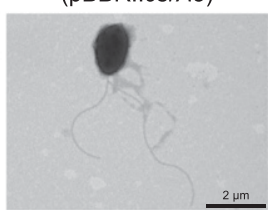

Fig. 4. CsrA2 and CsrA3 do not inhibit flagella synthesis in Pseudomonas syringae pv. tomato DC3000. A, Expression analysis of fliC in DC3000 and mutants determined by $\beta$-galactosidase assays. Activity from a translational fusion of the fliC promoter to 'lac $Z$ was measured in cell extracts from the indicated strains grown in polyacrylamide gel ( $0.5 \%$ agar) plates for $24 \mathrm{~h}$ at $20^{\circ} \mathrm{C}$ (swarmer cells). The graph shows the average activity of strains with pBBR1-MCS5 (light gray) and complemented with pBBR1-MCS5::csrA1, $\operatorname{csr} A 2$, or $\operatorname{csr} A 3$ (dark gray). Error bars correspond to the standard deviation of at least three biological replicates. B, Visualization of flagellar abundance in swarmer cells. Representative transmission electron microscopy photographs of swarmer cells negatively stained are shown. No significant differences were evident in the number of flagella per cell or their morphology. a translational repressor, and one or several of the $r \operatorname{smX} 1$ to $r \operatorname{smX} 5, \operatorname{rsm} Y$, and $r s m Z$ RNAs, whose transcription is activated by GacA, bind CsrA3, counteracting its repressor activity (Chatterjee et al. 2003; Moll et al. 2010; Valverde et al. 2003; Vargas et al. 2013). Nevertheless, it cannot be ruled out that one or more other genes involved in alginate production may also be molecular targets of CsrA3.

Motility is another trait controlled by the Gac-rsm system in various Pseudomonas strains, sometimes acting as an inhibitor and sometimes as an activator. A $P$. aeruginosa gacA mutant exhibits faster swarming motility and increased FliC (flagellin) and FliD (the filament capping protein) production (Kay et al. 2006). Similarly, the $P$. fluorescens F113 gacS and gacA mutants present bigger swimming halos than the wild type (Martínez-Granero et al. 2012; Navazo et al. 2009). However, DC3000 and other P. syringae gacA and gacS mutants were severely impaired in swimming and swarming (Chatterjee et al. 2003; Kinscherf and Willis 1999; 2002; Vargas et al. 2013). We have shown that CsrA3 and CsrA2 negatively regulate swarming motility in DC3000, similarly to RsmA in Serratia marcescens, Proteus mirabilis, or Pectobacterium wasabiae. In all those cases, the knock-out mutants were faster swarmers, whereas $\operatorname{csr} A$ /rsmA overexpression inhibited swarming (Ang et al. 2001; Kõiv et al. 2013; Liaw et al. 2003). Curiously, this effect is contrary to that observed in $P$. aeruginosa PAO1, whose $\operatorname{rsm} A$ mutant showed reduced swarming and swimming motility (Burrowes et al. 2006; Heurlier et al. 2004), $P$. fluorescens F113, in which overexpression of either rsmA or rsmE resulted in enhanced swimming motility (MartínezGranero et al. 2012), or P. putida KT2440, whose mutants lacking one or several of its three RsmA proteins exhibited reduced swimming and swarming (Huertas-Rosales et al. 2016). Also, overexpression of the $P$. aeruginosa $r s m A$ gene in different $P$. syringae strains inhibited swarming motility (Kong et al. 2012). Thus, although the components of the Gac-rsm pathway present in phylogenetically related bacteria and the phenotypes controlled are the same, the result of this regulation may be opposite. Therefore, identifying the target mRNAs bound by the CsrA proteins and their mode of action (repression or activation) is essential to establish the outcome of regulation.

First, we verified that the lack of flagellar functionality was not responsible for the $\operatorname{csr} A 2$-and $\operatorname{csr} A 3$-overexpressing strains swarming phenotype by performing swimming motility assays. The mutants had functional flagella in those conditions and only the overexpression of csrA3 slightly diminished swimming (Fig. 3A). We also studied flagella production and flagellin expression under swarming conditions, observing that they were similar to the wild type (Fig. 4A to C). This agrees with the observation that $\mathrm{CsrA} 3$ and $\mathrm{Csr} A 2$ negative regulation of swarming motility takes place on $s y f R$ and $s y f A B C$ expression and syringafactin production. The mutants rapidly swarmed across the plates and produced elevated amounts of syringafactin. Accordingly, syfR and syfA expression in $\Delta c s r A 3$ and $\triangle \operatorname{csr} A 2$ was higher than in the wild type, whereas $\operatorname{csr} A 3$ and $c s r A 2$ overexpression provoked the opposite effect. Thus, we have determined that fliC is not under CsrA3 and CsrA2 control in DC3000 (at least under swarming conditions), but the production of the biosurfactant syringafactin is. It is important to highlight that syringafactin is strictly required for DC3000 swarming motility (Berti et al. 2007; Burch et al. 2010; Nogales et al. 2015). Therefore, CsrA3 has a major role in the switch to a swarming phenotype in DC3000, CsrA2 also intervenes but less effectively, and CsrA1 does not participate at all. This is the first time that syringafactin production has been shown to be controlled by the CsrA proteins in DC3000, although Gac-rsm regulation of syringafactin was first described in $P$. syringae pv. 
A
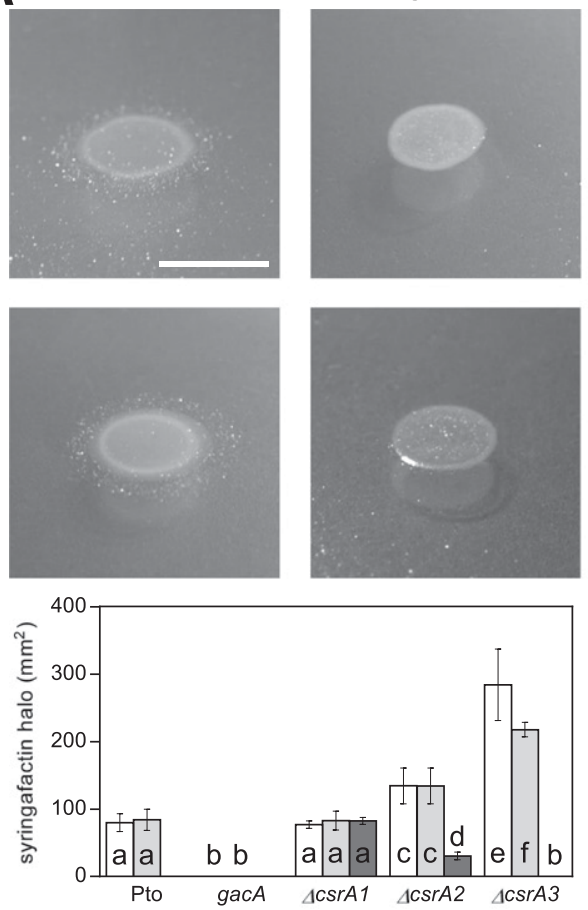

B

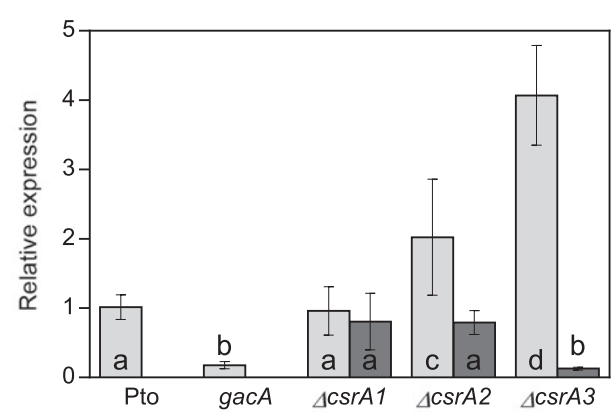

C

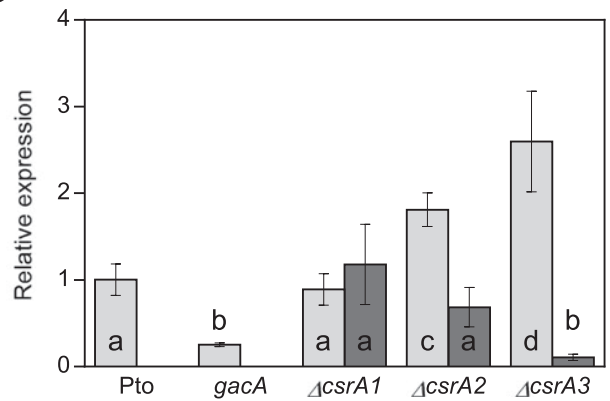

$\triangle \operatorname{csr} A 1$
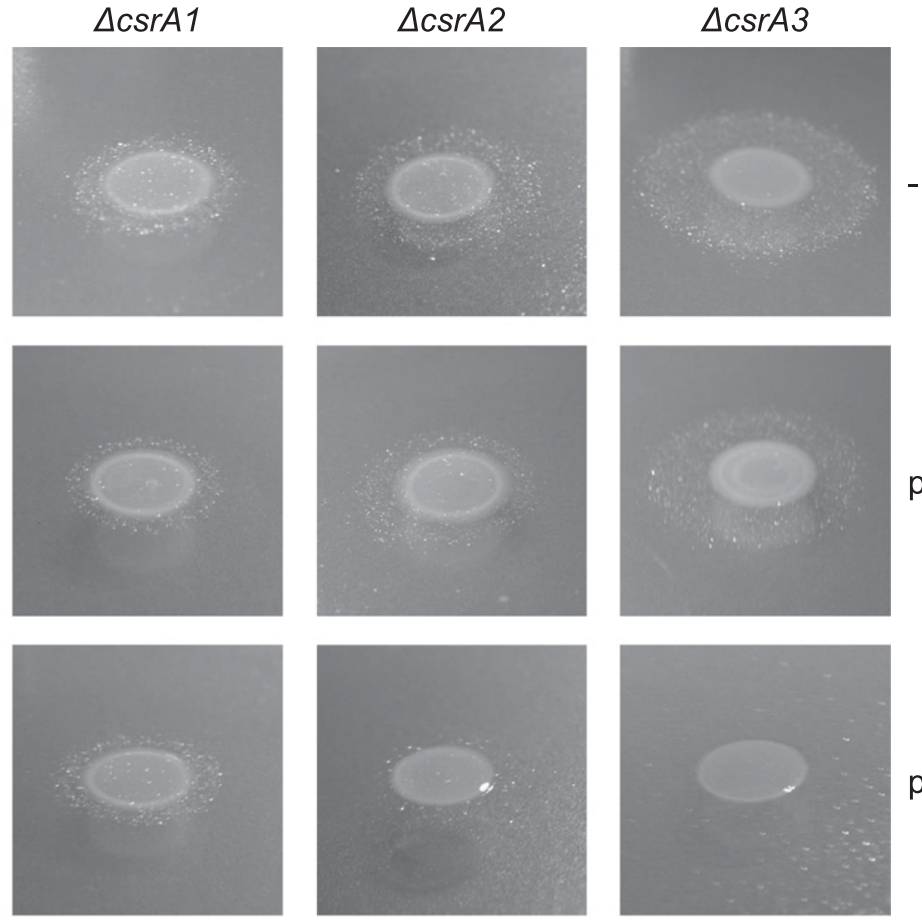

pBBR1-MCS5

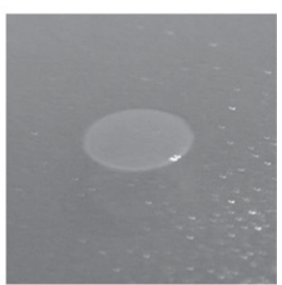

pBBR::csrA*
D

$\beta$-gal

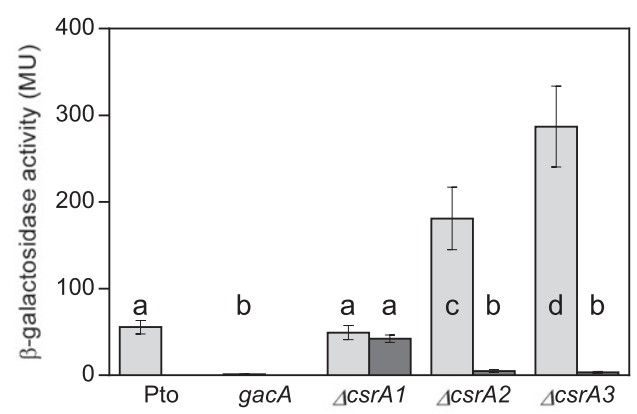

syfA

E

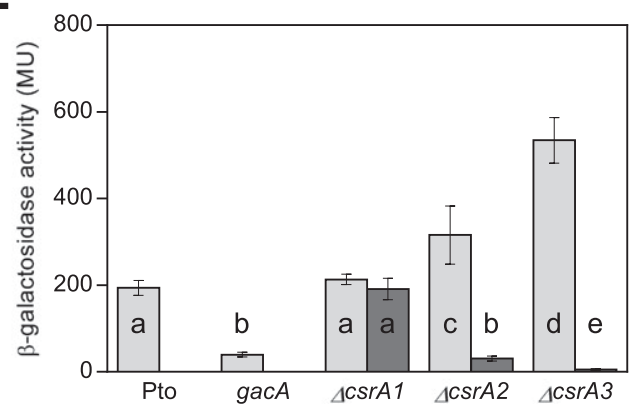

syfR

Fig. 5. CsrA2 and CsrA3 inhibit syringafactin expression and production in Pseudomonas syringae pv. tomato DC3000. A, Comparison of surfactant-induced halos around bacterial colonies. The indicated strains were grown on Luria-Bertani (1\% agar) for $24 \mathrm{~h}$ at $20^{\circ} \mathrm{C}$ and were visualized by the atomized oil assay. The biosurfactant areas of strains without plasmid (white), with pBBR1-MCS5 (light gray), and complemented with $c s r A 1$, csrA2, or csrA3 cloned into pBBR1-MCS5 (dark gray) were calculated and the means and standard deviations of three experiments with four replicates were plotted, with lower case letters a to $\mathrm{f}$ denoting analysis of variance (ANOVA) categories with significant differences $(P<0.01)$. The white scale bar represents $1 \mathrm{~cm}$. B and $\mathbf{C}$, Expression analysis of $s y f A$ and $s y f R$ in DC3000 and mutants determined by quantitative reverse transcription-polymerase chain reaction. Total RNAs were obtained from swarming bacteria grown on polyacrylamide gel (PAG) plates at $20^{\circ} \mathrm{C}$ for $24 \mathrm{~h}$. Expression values were normalized with the housekeeping gene gyrA and referred to the wild-type condition. The graph shows the average mRNA levels, and error bars correspond to the standard deviation of three biological replicates. Lower case letters a to d denote ANOVA categories with significant differences $(P<0.01)$. D and $\mathbf{E}$, Expression analysis of $s y f A$ and syfR in DC 3000 and mutants determined by $\beta$-galactosidase assays. Activity from the translational fusions of the $s y f A$ or $s y f R$ promoters to 'lacZ was determined in the indicated strains recovered from swarming plates. The measurements were carried out in cell extracts obtained from bacteria grown on PAG (0.5\% agar) plates for $24 \mathrm{~h}$ at $20^{\circ} \mathrm{C}$ (swarmer cells). The graph shows the average activity, and error bars correspond to the standard deviation of three biological replicates. Lower case letters a to e denote ANOVA categories with significant differences $(P<0.01)$. 
syringae B728a (Hockett et al. 2013). Also, lipopeptide production in P. entomophila and P. fluorescens SS101 was shown to be regulated by the Gac-rsm system (Song et al. 2014; ValletGely et al. 2010). Specifically, RsmA1 and RsmA2 (the CsrA2 and CsrA3 homologs, respectively) from P. entomophila are involved in the control of entolysin production (Vallet-Gely et al. 2010) and RsmA and RsmE (CsrA2 and CsrA3 orthologs, respectively) but not CsrA (CsrA1-like), are involved in Gac-rsm regulation of massetolide biosynthesis in P. fluorescens SS101 (Song et al. 2014).

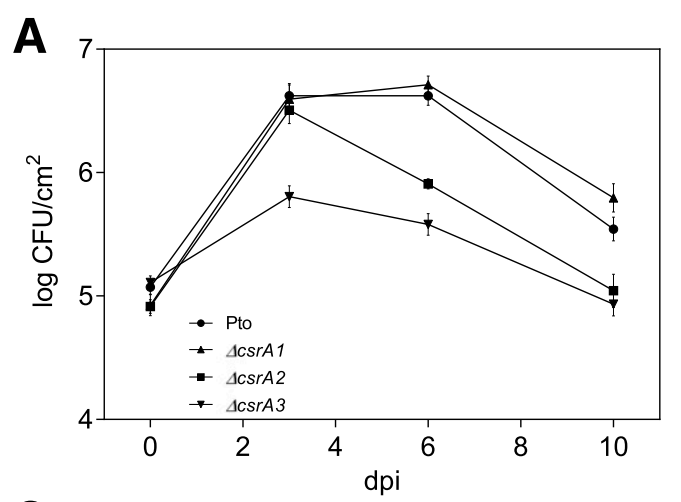

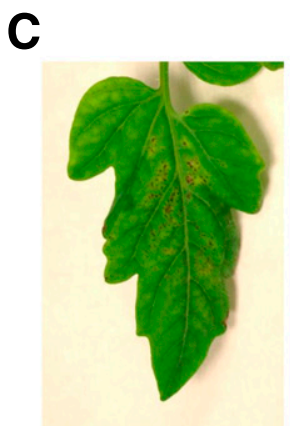

Pto

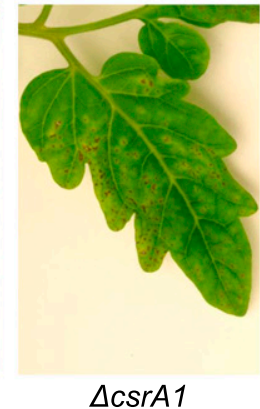

$\triangle \operatorname{csrA1}$

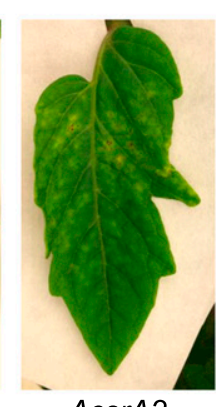

$\triangle c s r A 2$
D

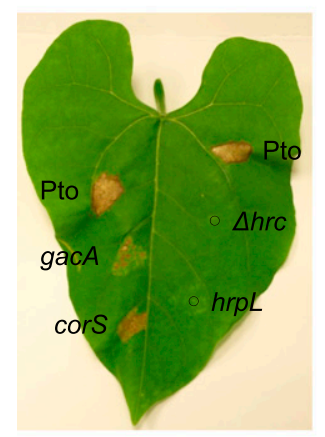

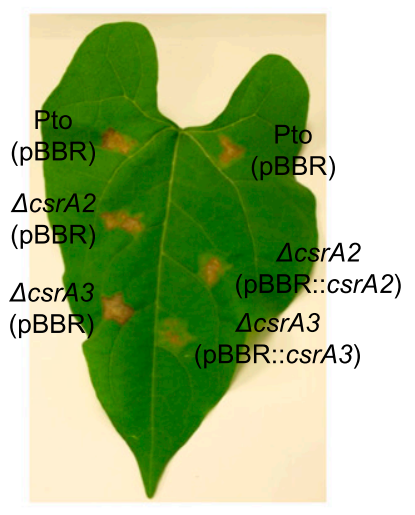

$\triangle c s r A 3$ (pBBR)
$\mathbf{F}$

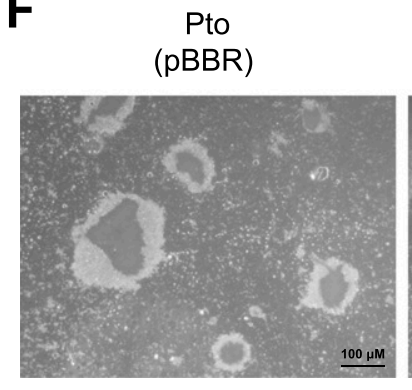

Analysis of the syfA putative $5^{\prime}$ leader revealed the presence of two consensus binding sites for CsrA proteins, i.e., GGA and AGGA, the latter within the SD region (Supplementary Fig. S7). Interestingly, several CsrA consensus binding sites were also found upstream of the syfR gene: one GGA and two AGGA motifs, one overlapping the SD and the other overlapping the first ATG. This situation is similar to that of $P$. fluorescens SS101, in which GacS controls massetolide A gene expression through a LuxR-like regulator (Song et al. 2014). Therefore, we propose that the Gac-rsm system exerts a double control on the
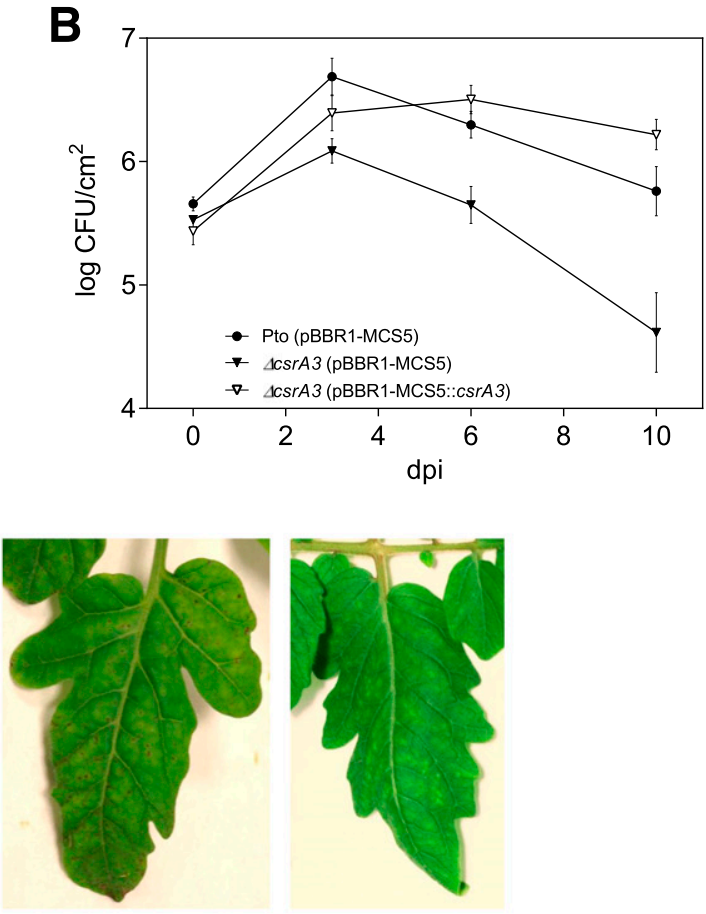

$\triangle \operatorname{csr} A 3(\operatorname{csr} A 3)$

$\mathbf{E}$

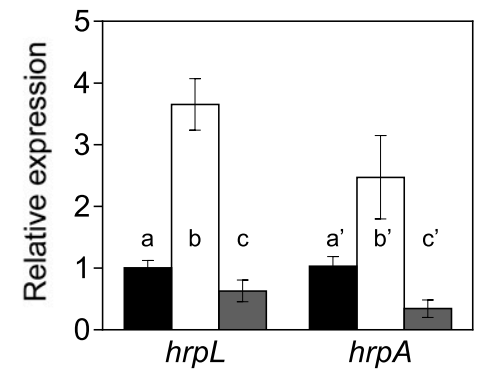

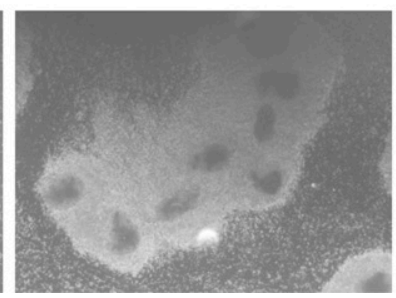

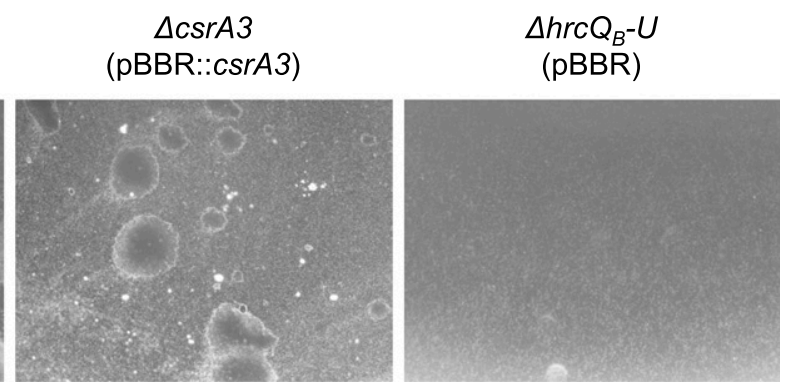

$\triangle h r c Q_{B}-U$ (pBBR) 
syringafactin biosynthesis genes in DC3000, directly through CsrA 2 and CsrA 3 binding to the syfABCD transcript and indirectly through syfR.

Regarding virulence, the ability of $\Delta \operatorname{csr} A 3$ to colonize the host was severely reduced, although the symptoms were similar to those provoked by the wild type. Therefore, CsrA3 is important for endophytic colonization and disease phenotypes, since it stimulates growth in plants and limits symptom development. A similar behavior (decrease in growth rate and increased virulence) was observed in Pectobacterium wasabiae after disrupting its $r s m A 2$ gene (Kõiv et al. 2013). The rsmA 2 mutant also exhibited a higher propensity to swarm and produce plant cell wall-degrading enzymes as the wild type, but, despite its efficient tissue maceration, $r s m A 2$ populations within the host were reduced. Our current model is that, in the absence of CsrA3, DC3000 acquires a hypervirulent phenotype characterized by enhanced swarming as well as elevated T3SS expression and effector export to the plant cells. However, the lack of control over these costly energetic processes, which involve multiple components and regulatory pathways, may result in decreased growth rate and fitness. On the contrary, the strain overexpressing csrA3 was capable of growth in the apoplast but lacked disease symptoms. This is consistent with the previously observed behavior of a $P$. syringae pv. syringae lemA ( gacS) mutant, which was not altered in its ability to colonize bean leaves but lost the ability to cause a pathogenic response (Willis et al. 1990). The authors suggested that lesion formation was not dependent on in planta growth. Here, we have found that the linkage of growth and symptom development seems to be under the control of CsrA3. We propose that $\mathrm{CsrA} 3$ functions as a pivotal regulator of the DC3000 life cycle, repressing virulence traits and coordinately promoting cell division under noninducing conditions (i.e., in laboratory media and, likely, at late stages of host infection). When DC3000 senses the plant, the activated GacS/A TCS relieves CsrA repression of swarming and T3SS, among others, inducing the infective phenotype. Further work is needed to discover new traits selectively regulated by this protein and to elucidate how growth and symptom development can be unlinked.

Overall, the GacS/GacA TCS functions in conjunction with CsrA posttranscriptional regulators to allow DC3000 to sense and adapt to changes in the environment. We have shown that CsrA1, CsrA2, and CsrA3 RNA-binding regulatory proteins exert nonredundant functions and demonstrate that the loss of CsrA2 and, mainly, CsrA3 alter the expression of a variety of systems important for motility, EPS synthesis, growth, and virulence. Particularly, alginate synthesis, syringafactin production, and virulence are considerably de-repressed, whereas growth in planta is impaired. The phenotypic assays together with sequence analysis have allowed us to propose a series of target genes for the CsrA proteins. This provides the basis for future protein-RNA interaction assays that will allow a better understanding of the roles and modes of action of the different paralogs in DC3000.

\section{MATERIALS AND METHODS}

Bacterial strains, plasmids, and culture media.

The bacterial strains used are listed in Supplementary Table S2. P. syringae pv. tomato DC3000 strains were routinely grown in LB medium (Sambrook et al. 1989) at $28^{\circ} \mathrm{C}$ or in MMR ( $7 \mathrm{mM}$ Na-glutamate, $55 \mathrm{mM}$ mannitol, $1.31 \mathrm{mM}$ $\mathrm{K}_{2} \mathrm{HPO}_{4}, 2.2 \mathrm{mM} \mathrm{KH}_{2} \mathrm{PO}_{4}, 0.61 \mathrm{mM} \mathrm{MgSO} 4,0.34 \mathrm{mM} \mathrm{CaCl}_{2}$, $0.022 \mathrm{mM} \mathrm{FeCl}_{3}, 0.85 \mathrm{mM} \mathrm{NaCl}$ ) minimal medium (Robertsen et al. 1981) at $20^{\circ} \mathrm{C}$. The T3SS-inducing minimal medium MMF [50 mM K-phosphate buffer, $\mathrm{pH} 5.7,7.6 \mathrm{mM}\left(\mathrm{NH}_{4}\right)_{2} \mathrm{SO}_{4}$, $1.7 \mathrm{mM} \mathrm{MgCl}_{2}, 1.7 \mathrm{mM} \mathrm{NaCl}$, and $10 \mathrm{mM}$ fructose] was used for certain experiments (Huynh et al. 1989). P. syringae pv. tomato cells were grown at $25^{\circ} \mathrm{C}$ in LB to an optical density at $660 \mathrm{~nm}\left(\mathrm{OD}_{660}\right)$ of 0.5 , were washed, and were incubated in the T3SS-inducing MMF medium for $24 \mathrm{~h}$ at $20^{\circ} \mathrm{C}$. When required, antibiotics were added to the cultures or plates: gentamicin $(5 \mu \mathrm{g} / \mathrm{ml})$, kanamycin $(\mathrm{Km})(50 \mu \mathrm{g} / \mathrm{ml})$, rifampicin $(10 \mu \mathrm{g} / \mathrm{ml})$, streptomycin $(\mathrm{Sm})(25 \mu \mathrm{g} / \mathrm{ml})$, and tetracycline $(10 \mu \mathrm{g} / \mathrm{ml})$.

We constructed plasmids bearing the $\operatorname{csr} A 1, \operatorname{csr} A 2$, and $\operatorname{csr} A 3$ genes for in trans complementation. A fragment including each csrA gene was amplified, by PCR, from $P$. syringae pv. tomato DC3000 chromosomal DNA, using specific oligonucleotides (Supplementary Table S3). Those DNAs were ligated into pGEM-T (Promega), were sequenced, and were cloned into pBBR1-MCS5 (Kovach et al. 1995) after digestion with EcoRI under the control of the plasmid lac promoter.

The plasmids carrying $f l i C$, syfA, and syfR translational fusions to ' $l a c Z$ were constructed by cloning promoter fragments generated by PCR. Those PCR fragments were ligated into pGEM-T, were sequenced, and were then cloned into pME6015 after digestion with the appropriate restriction enzymes. The 593 -pb $f l i C$ promoter fragment includes $270 \mathrm{nt}$ encoding the first 90 aa of FliC, the 371-pb syfA promoter fragment contains 81 nt encoding the first 27 aa of SyfA, and the 399-pb syfR promoter fragment comprises 99 nt encoding the first 33 aa of SyfR.

Plasmid pQN8 is a pGEM-T derivative that carries a 1,380 bp fragment, generated by PCR, harboring part of the alg 8 and alg $D$ genes. Upon digestion with $B g l \mathrm{II}$, a unique site in $\operatorname{alg} 8$, the plasmid was ligated to a $2.056-\mathrm{kb} \Omega \mathrm{Sm} / \mathrm{Sp}$ interposon from

Fig. 6. Bacterial growth and symptom development on tomato leaves. A, Time course of growth of Pseudomonas syringae pv. tomato DC3000 and $\Delta$ csrA mutants in the primary leaves of tomato plants. CFU were quantified at $0,3,6$, and 10 days postinoculation (dpi) with approximately $10^{8} \mathrm{CFU} / \mathrm{ml}$ by spray. Data represent the average of four experiments with their standard error. At 3 dpi, only populations of the $\Delta c s r A 3$ mutant were significantly different from the rest. At 6 and $10 \mathrm{dpi}$, wild-type and $\Delta c s r A 1$ populations were significantly different from those of the $\Delta c s r A 3$ and the $\Delta c s r A 2$ mutants, as determined by one-way analysis of variance (ANOVA) $(P<0.01)$. B, Time course of growth of DC3000 (pBBR1-MCS5), $\Delta c s r A 3$ (pBBR1-MCS5), and $\Delta c s r A 3$ (pBBR1-MCS5:: $c s r A 3)$ in the primary leaves of tomato plants after inoculation by spray. Data represent the average of three experiments with their standard error. The overexpression of $c s r A 3$ in the mutant allowed similar growth to the wild type, as determined by one-way ANOVA $(P<0.01)$. C, Development of symptoms induced on tomato leaves 10 days after inoculation with DC3000 and different mutants at $10^{8} \mathrm{CFU} / \mathrm{ml}$ by spray. The severity of symptoms induced by $\Delta c s r A 3$ (pBBR1-MCS5::csrA3) was significantly lower than the others. D, Hypersensitive response (HR) in bean when inoculated with different DC3000 mutants. Symptoms induced on bean leaves 8 dpi with DC3000 and different mutants at $10^{7} \mathrm{CFU} / \mathrm{ml}$. Only $h r p L$ and $\Delta h r c Q b-U$ were unable to elicit HR at all, whereas symptoms caused by gacA and $\Delta c s r A 3$ (pBBR1-MCS5::csrA3) were significantly reduced. E, Expression analysis of $h r p L$ and $h r p A$ in DC3000 (pBBR1MCS5) (black bars), $\Delta$ csrA3 (pBBR1-MCS5) (white bars), and $\Delta$ csrA3 (pBBR1-MCS5::csrA3) (gray bars) determined by quantitative reverse transcriptionpolymerase chain reaction. Total RNAs were obtained from cultures grown for $24 \mathrm{~h}$ in MMF [50 mM K-phosphate buffer, $\mathrm{pH} 5.7,7.6 \mathrm{mM}\left(\mathrm{NH}_{4}\right)_{2} \mathrm{SO}_{4}, 1.7 \mathrm{mM}$ $\mathrm{MgCl}_{2}, 1.7 \mathrm{mM} \mathrm{NaCl}$, and $10 \mathrm{mM}$ fructose]. Expression values were normalized with the housekeeping gene gyrA and referred to the wild-type condition. The graph shows the average mRNA levels and error bars correspond to the standard deviation of three biological replicates. Lower case letters a to $\mathrm{c}$ and a' to $\mathrm{c}$ ' denote ANOVA categories with significant differences $(P<0.01)$. F, Auto-agglutination assays. Agglutinates micrographs of the indicated strains after $24 \mathrm{~h}$ of incubation in MMF medium. Scale bar represents $100 \mu \mathrm{m}$.
} 
$\mathrm{pHP} 45 \Omega \mathrm{Sm} / \mathrm{Sp}$ (Fellay et al. 1987) to yield pQN8 $\Omega \mathrm{Sm}$, which was used for in vivo gene replacement.

\section{Construction of directed mutants.}

We constructed $\Delta \operatorname{csr} A^{*}$ directed mutants by deleting most of their open reading frames (ORFs). First, a region with $\operatorname{csr} A 2$ or $c s r A 3$ adjacent sequences but lacking their ORFs were amplified by PCR with specific oligonucleotides and were cloned into $\mathrm{pK} 18 m o b s a c B$, which does not replicate in $P$. syringae. The $\mathrm{Km}^{\mathrm{R}}$ sucrose-sensitive plasmids were then electroporated into DC3000. Electro-competent cells (Choi et al. 2006) were mixed with DNA (0.3 to $0.5 \mu \mathrm{g}$ of DNA per milliliter of cell suspension), were transferred to $0.1-\mathrm{cm}$ cuvettes, and were submitted to a $1.800 \mathrm{~V}$ pulse for $5 \mathrm{~ms}$, by using an Eppendorf electroporator 2510. Transformants were selected in $\mathrm{Km}(50 \mu \mathrm{g} / \mathrm{ml})$, were screened for sucrose sensitivity (15\% [wt/vol]), and were then grown in LB to force plasmid loss. Cells were then plated on LB with sucrose (15\% [wt/vol]) and the sucrose-resistant and $\mathrm{Km}^{\mathrm{S}}$ colonies, which were expected to be double-recombinants, were selected and were checked by PCR or sequencing.

The alg 8 null mutant was constructed by gene replacement. The ampicillin-resistant $\left(\mathrm{Ap}^{\mathrm{R}}\right) \mathrm{Sm}^{\mathrm{R}}$ pQN8$\Omega$ Sm suicide plasmid was electroporated into DC3000 and transformants that acquired the inactivated gene $\left(\mathrm{Sm}^{\mathrm{R}}\right)$ were selected and were screened for Ap sensitivity $(100 \mu \mathrm{g} / \mathrm{ml})$. Two $\mathrm{Sm}^{\mathrm{R}} / \mathrm{Ap}^{\mathrm{S}}$ clones were chosen and were confirmed by Southern blot to have the wild-type gene replaced by alg $8:: \Omega S m$. The double mutants alg $8 / \operatorname{csr} A 3$ and syfA/csrA3 were constructed as the $\triangle \operatorname{csr} A 3$ single mutant, but the pK18mobsacB:: $\Delta \operatorname{csr} A 3$ plasmid was electroporated into the alg 8 or $\Delta$ syfA mutants.

\section{Alginate quantification.}

Three-day plate cultures of DC3000 or mutants on MMR medium at $20^{\circ} \mathrm{C}$ (or on $\mathrm{LB}$ at $28^{\circ} \mathrm{C}$ ) were used for alginate extraction and quantification by the carbazole method, described previously (May and Chakrabarty 1994). Briefly, cells were washed from each plate, were resuspended in $0.9 \% \mathrm{NaCl}$, and were then centrifuged for $30 \mathrm{~min}$ at $3,300 \times g$. To precipitate alginate, the supernatant was combined with three volumes of $95 \%$ ethanol, were incubated $16 \mathrm{~h}$ at $-20^{\circ} \mathrm{C}$, were centrifuged for $30 \mathrm{~min}$ at $38,500 \times \mathrm{g}$, and the dried pellet was resuspended in milliQ $\mathrm{H}_{2} \mathrm{O}$. Alginate solution $(140 \mu \mathrm{l})$ was mixed with 1,200 $\mu \mathrm{l}$ of borate-sulfuric acid (the borate stock solution $\left[24.74 \mathrm{~g}\right.$ of $\mathrm{H}_{3} \mathrm{BO}_{3}$ in $45 \mathrm{ml}$ of $4 \mathrm{M} \mathrm{KOH}$ that was diluted in $100 \mathrm{ml}$ of distilled water] was diluted 1:4 in concentrated sulfuric acid) and $40 \mu \mathrm{l}$ of the $0.1 \%$ (wt/vol in absolute ethanol) carbazole. In order to develop the color reaction, the mixture was heated at $55^{\circ} \mathrm{C}$ for $30 \mathrm{~min}$. Finally, the OD was measured at $530 \mathrm{~nm}$. Alginic acid from seaweed (Macrocystis pyrifera; Sigma) was used as a standard in these experiments. Alginate levels of each strain were standardized by total protein of the initial sample determined by Bradford assay (Bio-Rad protein assay kit) and were expressed in micrograms of uronic acids to milligrams of total cell protein. Each experiment was repeated at least three times.

\section{RNA preparation and assays.}

Cells were harvested from swarming plates incubated at $20^{\circ} \mathrm{C}$ for $24 \mathrm{~h}$, LB plates incubated at $28^{\circ} \mathrm{C}$ for 2 days, or MMF auto-agglutination cultures, were pelleted, were frozen in liquid nitrogen, and were processed for RNA isolation using TRI ReagentLS (Molecular Research Center), as described before (Vargas et al. 2013). For qRT-PCR, we proceeded as previously described (Nogales et al. 2015; Vargas et al. 2013), and expression values were normalized with the housekeeping gene gyrA and referred to the wild-type condition.

\section{Motility experiments.}

For swimming assays, DC3000 and mutants were grown on LB plates for $48 \mathrm{~h}$ and were resuspended in $10 \mathrm{mM} \mathrm{MgCl}_{2}$. The bacterial suspension $(2 \mu \mathrm{l})\left(\mathrm{OD}_{660}=2.0\right)$ were stabbed into $\mathrm{LB}$ plates $\left(0.3 \%\right.$ agar) and were incubated at $20^{\circ} \mathrm{C}$ for $48 \mathrm{~h}$, when the swimming halo diameters were measured. For swarming assays, the $2-\mu l$ aliquots were dropped in the center of PG-agar plates, were incubated at $20^{\circ} \mathrm{C}$, and were observed after $24 \mathrm{~h}$. Negative staining of swarmer cells to visualize flagella by TEM was performed, as described previously (Nogales et al. 2015). Three motility plates were used for each strain, and the experiment was repeated with three independent cultures.

\section{Detection of syringafactin.}

Syringafactin was detected with the atomized oil assay previously described (Burch et al. 2010). DC3000 and mutants were grown on LB plates for $48 \mathrm{~h}$ and were resuspended in sterile milliQ water. Aliquots $(10 \mu \mathrm{l})\left(\mathrm{OD}_{660}=1.0\right)$ were pipetted onto the surface of LB plates, were incubated $24 \mathrm{~h}$ at $20^{\circ} \mathrm{C}$, and were then sprayed with a mist of mineral oil. The diameter of the visible halo of brighter oil drops was measured and the area of the producing bacterial colony was calculated and was substracted from that of the surfactant halo, to yield the adjusted halo area.

\section{$\boldsymbol{\beta}$-galactosidase assays.}

Bacterial cells from swarming plates were resuspended in milliQ water and were adjusted to an $\mathrm{OD}_{660}$ of 0.5 . $\beta$-galactosidase activity was determined in triplicate in permeabilized cells (Miller 1972).

\section{Infection assays.}

Seeds of Solanum lycopersicum cv. Moneymaker (a P. syringae pv. tomato S line, i.e., a compatible host for DC3000) were germinated and were grown, with 16-h light and 8-h dark cycles, $24^{\circ} \mathrm{C}$ day and $16^{\circ} \mathrm{C}$ night temperatures, and $70 \%$ relative humidity, in a plant growth chamber. DC3000 strains grown on $\mathrm{LB}$ plates for $48 \mathrm{~h}$ at $28^{\circ} \mathrm{C}$ were suspended in $10 \mathrm{mM}$ $\mathrm{MgCl}_{2}$, the concentration was adjusted to $10^{8} \mathrm{CFU} / \mathrm{ml}$, and the strains were applied to one leaf of three different plants with an airbrush until the leaf (adaxial and abaxial) surface was uniformly wet. The analysis of symptom development and sampling were performed $3 \mathrm{~h}$ after inoculation (time 0 ), when the leaves were dried, and several days after inoculation $(3,6$, and $10 \mathrm{dpi}$ ) to monitor bacterial growth in planta. Bacteria were recovered from the infected leaves using a $10-\mathrm{mm}$ diameter cork-borer, sampling 20 disks per plant. Five disks $\left(3.9 \mathrm{~cm}^{2}\right)$ were homogenized by mechanical disruption into $1 \mathrm{ml}$ of $10 \mathrm{mM} \mathrm{MgCl} 2$ and were counted by plating serial dilutions onto LB plates with the corresponding antibiotics. The severity of symptoms was evaluated as the percentage of necrotic area per leaflet induced by the inoculated strains at 10 dpi. The necrotic areas were digitally measured, using ImageJ (Abràmoff et al. 2004), on five inoculated leaflets of at least three different plants.

\section{HR assays.}

Seeds of Phaseolus vulgaris cv. Canadian Wonder were germinated and grown in pots, with 16-h light and 8-h dark cycles, at $24^{\circ} \mathrm{C}$ day and $16^{\circ} \mathrm{C}$ night temperatures, and $70 \%$ relative humidity, in a plant growth chamber. DC3000 strains were suspended in $10 \mathrm{mM} \mathrm{MgCl}_{2}\left(10^{7} \mathrm{CFU} / \mathrm{ml}\right)$ and were infiltrated on a small area of the abaxial leaf surface using a blunt syringe. The symptoms were visualized every day until 8 dpi. The experiments were performed two times with five replicates each. 


\section{Auto-agglutination assays.}

Bacterial strains were grown on LB plates for $48 \mathrm{~h}$ and were resuspended in milliQ water. Inoculums $\left(\mathrm{OD}_{660}=0.05\right)$ were incubated in $\mathrm{LB} 12 \mathrm{~h}$, at $25^{\circ} \mathrm{C}$, to reach an $\mathrm{OD}_{660}=0.5$. Then, the cultures were washed twice and were adjusted to $\mathrm{OD}_{660}=$ 0.5 in MMF medium and were incubated at $20^{\circ} \mathrm{C}$ and $90 \mathrm{rpm}$. After $24 \mathrm{~h}$, two samples of each strain were taken, were wet-mounted, and were observed under a Zeiss Axioskope microscope. All experiments were performed at least three times.

\section{Statistical analysis.}

Statistical comparison among different strains or conditions was performed by one-way analysis of variance with posthoc Tukey highly significant differences test using R.

\section{Sequence comparison of CsrA proteins.}

The sequences were aligned using ClustalW. The dendrogram was generated by the neighbor-joining method and was rooted with the E. coli CsrA (b2696) sequence. These analyses were conducted with MEGA7 (Kumar et al. 2016).

\section{ACKNOWLEDGMENTS}

We thank A. Felipe and S. Muñoz for their technical assistance. We also thank C. Waite for the $c s r A 1$, A. Chatterjee for the gacA, M. Ullrich for the $c o r S$, and E. López-Solanilla for the $h r c Q_{b}-U$ mutants. This research was supported by grant BIO2014-55075-P from the Spanish Ministry of Economy, Industry and Competitiveness cofinanced by European Regional Development Fund. M.-D. Ferreiro was supported by a FPU contract from the Spanish MECD (FPU14/02120) and G. A. Farias by a Ciência sem Fronteiras fellowship (BEX10043/13-6, CAPES-Brazil). PAIDI group BIO-180 belongs to the Agrifood Campus of International Excellence ceiA3.

\section{LITERATURE CITED}

Abràmoff, M. D., Magalhães, P. J., and Ram, S. J. 2004. Image processing with ImageJ. Biophoton. Int. 11:36-42.

Ang, S., Horng, Y. T., Shu, J. C., Soo, P. C., Liu, J. H., Yi, W. C., Lai, H. C., Luh, K. T., Ho, S. W., and Swift, S. 2001. The role of RsmA in the regulation of swarming motility in Serratia marcescens. J. Biomed. Sci. 8:160-169.

Berti, A. D., Greve, N. J., Christensen, Q. H., and Thomas, M. G. 2007. Identification of a biosynthetic gene cluster and the six associated lipopeptides involved in swarming motility of Pseudomonas syringae pv. tomato DC3000. J. Bacteriol. 189:6312-6323.

Blumer, C., Heeb, S., Pessi, G., and Haas, D. 1999. Global GacA-steered control of cyanide and exoprotease production in Pseudomonas fluorescens involves specific ribosome binding sites. Proc. Natl. Acad. Sci. U.S.A. 96:14073-14078.

Brencic, A., McFarland, K. A., McManus, H. R., Castang, S., Mogno, I., Dove, S. L., and Lory, S. 2009. The GacS/GacA signal transduction system of Pseudomonas aeruginosa acts exclusively through its control over the transcription of the RsmY and RsmZ regulatory small RNAs. Mol. Microbiol. 73:434-445.

Burch, A. Y., Shimada, B. K., Browne, P. J., and Lindow, S. E. 2010. Novel high-throughput detection method to assess bacterial surfactant production. Appl. Environ. Microbiol. 76:5363-5372.

Burch, A. Y., Shimada, B. K., Mullin, S. W., Dunlap, C. A., Bowman, M. J., and Lindow, S. E. 2012. Pseudomonas syringae coordinates production of a motility-enabling surfactant with flagellar assembly. J. Bacteriol. 194:1287-1298.

Burrowes, E., Baysse, C., Adams, C., and O'Gara, F. 2006. Influence of the regulatory protein RsmA on cellular functions in Pseudomonas aeruginosa $\mathrm{PAO} 1$, as revealed by transcriptome analysis. Microbiology 152:405-418.

Cha, J. Y., Lee, D. G., Lee, J. S., Oh, J. I., and Baik, H. S. 2012. GacA directly regulates expression of several virulence genes in Pseudomonas syringae pv. tabaci 11528. Biochem. Biophys. Res. Commun. 417:665-672.

Chatterjee, A., Cui, Y., Yang, H., Collmer, A., Alfano, J. R., and Chatterjee, A. K. 2003. GacA, the response regulator of a two-component system, acts as a master regulator in Pseudomonas syringae pv. tomato DC 3000 by controlling regulatory RNA, transcriptional activators, and alternate sigma factors. Mol. Plant-Microbe Interact. 16:1106-1117.
Choi, K. H., Kumar, A., and Schweizer, H. P. 2006. A 10-min method for preparation of highly electrocompetent Pseudomonas aeruginosa cells: Application for DNA fragment transfer between chromosomes and plasmid transformation. J. Microbiol. Methods 64:391-397.

Collmer, A., Badel, J. L., Charkowski, A. O., Deng, W. L., Fouts, D. E., Ramos, A. R., Rehm, A. H., Anderson, D. M., Schneewind, O., van Dijk, K., and Alfano, J. R. 2000. Pseudomonas syringae Hrp type III secretion system and effector proteins. Proc. Natl. Acad. Sci. U.S.A. 97:8770-8777.

Duss, O., Michel, E., Yulikov, M., Schubert, M., Jeschke, G., and Allain, F. H. 2014. Structural basis of the non-coding RNA RsmZ acting as a protein sponge. Nature 509:588-592.

Fellay, R., Frey, J., and Krisch, H. 1987. Interposon mutagenesis of soil and water bacteria: A family of DNA fragments designed for in vitro insertional mutagenesis of gram-negative bacteria. Gene 52:147-154.

Gutiérrez, P., Li, Y., Osborne, M. J., Pomerantseva, E., Liu, Q., and Gehring, K. 2005. Solution structure of the carbon storage regulator protein CsrA from Escherichia coli. J. Bacteriol. 187:3496-3501.

Heeb, S., Blumer, C., and Haas, D. 2002. Regulatory RNA as mediator in GacA/RsmA-dependent global control of exoproduct formation in Pseudomonas fluorescens CHA0. J. Bacteriol. 184:1046-1056.

Heeb, S., and Haas, D. 2001. Regulatory roles of the GacS/GacA twocomponent system in plant-associated and other gram-negative bacteria. Mol. Plant-Microbe Interact. 14:1351-1363.

Heeb, S., Kuehne, S. A., Bycroft, M., Crivii, S., Allen, M. D., Haas, D., Cámara, M., and Williams, P. 2006. Functional analysis of the posttranscriptional regulator RsmA reveals a novel RNA-binding site. J. Mol. Biol. 355:1026-1036

Hernández-Eligio, A., Moreno, S., Castellanos, M., Castañeda, M., Nuñez, C., Muriel-Millán, L. F., and Espín, G. 2012. RsmA post-transcriptionally controls PhbR expression and polyhydroxybutyrate biosynthesis in Azotobacter vinelandii. Microbiology 158:1953-1963.

Heurlier, K., Williams, F., Heeb, S., Dormond, C., Pessi, G., Singer, D., Cámara, M., Williams, P., and Haas, D. 2004. Positive control of swarming, rhamnolipid synthesis, and lipase production by the posttranscriptional RsmA/RsmZ system in Pseudomonas aeruginosa PAO1. J. Bacteriol. 186: 2936-2945.

Hockett, K. L., Burch, A. Y., and Lindow, S. E. 2013. Thermo-regulation of genes mediating motility and plant interactions in Pseudomonas syringae. PLoS One 8:e59850.

Hrabak, E. M., and Willis, D. K. 1992. The lemA gene required for pathogenicity of Pseudomonas syringae pv. syringae on bean is a member of a family of two-component regulators. J. Bacteriol. 174: 3011-3020.

Huertas-Rosales, Ó., Ramos-González, M. I., and Espinosa-Urgel, M. 2016. Self-regulation and interplay of Rsm family proteins modulate the lifestyle of Pseudomonas putida. Appl. Environ. Microbiol. 82: 5673-5686.

Humair, B., Wackwitz, B., and Haas, D. 2010. GacA-controlled activation of promoters for small RNA genes in Pseudomonas fluorescens. Appl. Environ. Microbiol. 76:1497-1506.

Huynh, T. V., Dahlbeck, D., and Staskawicz, B. J. 1989. Bacterial blight of soybean: Regulation of a pathogen gene determining host cultivar specificity. Science 245:1374-1377.

Kay, E., Dubuis, C., and Haas, D. 2005. Three small RNAs jointly ensure secondary metabolism and biocontrol in Pseudomonas fluorescens CHA0. Proc. Natl. Acad. Sci. U.S.A. 102:17136-17141.

Kay, E., Humair, B., Dénervaud, V., Riedel, K., Spahr, S., Eberl, L., Valverde, C., and Haas, D. 2006. Two GacA-dependent small RNAs modulate the quorum-sensing response in Pseudomonas aeruginosa. J. Bacteriol. 188:6026-6033.

Kinscherf, T. G., and Willis, D. K. 1999. Swarming by Pseudomonas syringae $\mathrm{B} 728$ a requires gacS (lemA) and gacA but not the acyl-homoserine lactone biosynthetic gene ahlI. J. Bacteriol. 181:4133-4136.

Kinscherf, T. G., and Willis, D. K. 2002. Global regulation by gidA in Pseudomonas syringae. J. Bacteriol. 184:2281-2286.

Kõiv, V., Andresen, L., Broberg, M., Frolova, J., Somervuo, P., Auvinen, P., Tapio Palva, E., Pirhonen, M., Tenson, T., and Mäe, A. 2013. Lack of RsmA-mediated control results in constant hypervirulence, cell elongation, and hyperflagellation in Pectobacterium wasabiae. PLoS One 8: e54248.

Kong, H. S., Roberts, D. P., Patterson, C. D., Kuehne, S. A., Heeb, S., Lakshman, D. K., and Lydon, J. 2012. Effect of overexpressing rsmA from Pseudomonas aeruginosa on virulence of select phytotoxin-producing strains of $P$. syringae. Phytopathology 102:575-587.

Kovach, M. E., Elzer, P. H., Hill, D. S., Robertson, G. T., Farris, M. A., Roop, R. M., and Peterson, K. M. 1995. Four new derivatives of the broad-host-range cloning vector pBBR1MCS, carrying different antibioticresistance cassettes. Gene 166:175-176. 
Kulkarni, P. R., Cui, X., Williams, J. W., Stevens, A. M., and Kulkarni, R. V. 2006. Prediction of CsrA-regulating small RNAs in bacteria and their experimental verification in Vibrio fischeri. Nucleic Acids Res. 34: 3361-3369.

Kulkarni, P. R., Jia, T., Kuehne, S. A., Kerkering, T. M., Morris, E. R., Searle, M. S., Heeb, S., Rao, J., and Kulkarni, R. V. 2014. A sequencebased approach for prediction of CsrA/RsmA targets in bacteria with experimental validation in Pseudomonas aeruginosa. Nucleic Acids Res. 42:6811-6825.

Kumar, S., Stecher, G., and Tamura, K. 2016. MEGA7: Molecular evolutionary genetics analysis version 7.0 for bigger datasets. Mol. Biol. Evol. 33:1870-1874.

Lalaouna, D., Fochesato, S., Sanchez, L., Schmitt-Kopplin, P., Haas, D., Heulin, T., and Achouak, W. 2012. Phenotypic switching in Pseudomonas brassicacearum involves GacS- and GacA-dependent Rsm small RNAs. Appl. Environ. Microbiol. 78:1658-1665.

Lapouge, K., Schubert, M., Allain, F. H., and Haas, D. 2008. Gac/Rsm signal transduction pathway of gamma-proteobacteria: From RNA recognition to regulation of social behaviour. Mol. Microbiol. 67: 241-253.

Laville, J., Voisard, C., Keel, C., Maurhofer, M., Défago, G., and Haas, D. 1992. Global control in Pseudomonas fluorescens mediating antibiotic synthesis and suppression of black root rot of tobacco. Proc. Natl. Acad. Sci. U.S.A. 89:1562-1566.

Lenz, D. H., Miller, M. B., Zhu, J., Kulkarni, R. V., and Bassler, B. L. 2005. CsrA and three redundant small RNAs regulate quorum sensing in Vibrio cholerae. Mol. Microbiol. 58:1186-1202.

Liao, C. H., McCallus, D. E., and Fett, W. F. 1994. Molecular characterization of two gene loci required for production of the key pathogenicity factor pectate lyase in Pseudomonas viridiflava. Mol. Plant-Microbe Interact. 7:391-400.

Liaw, S. J., Lai, H. C., Ho, S. W., Luh, K. T., and Wang, W. B. 2003. Role of RsmA in the regulation of swarming motility and virulence factor expression in Proteus mirabilis. J. Med. Microbiol. 52:19-28.

Manzo, J., Cocotl-Yañez, M., Tzontecomani, T., Martínez, V. M., Bustillos, R., Velásquez, C., Goiz, Y., Solís, Y., López, L., Fuentes, L. E., Nuñez, C., Segura, D., Espín, G., and Castañeda, M. 2011. Post-transcriptional regulation of the alginate biosynthetic gene algD by the Gac/Rsm system in Azotobacter vinelandii. J. Mol. Microbiol. Biotechnol. 21:147-159.

Marden, J. N., Diaz, M. R., Walton, W. G., Gode, C. J., Betts, L., Urbanowski, M. L., Redinbo, M. R., Yahr, T. L., and Wolfgang, M. C. 2013. An unusual CsrA family member operates in series with RsmA to amplify posttranscriptional responses in Pseudomonas aeruginosa. Proc. Natl. Acad. Sci. U.S.A. 110:15055-15060.

Martínez-Granero, F., Navazo, A., Barahona, E., Redondo-Nieto, M., Rivilla, R., and Martín, M. 2012. The Gac-Rsm and SadB signal transduction pathways converge on $\mathrm{AlgU}$ to downregulate motility in Pseudomonas fluorescens. PLoS One 7:e31765.

May, T. B., and Chakrabarty, A. M. 1994. Isolation and assay of Pseudomonas aeruginosa alginate. Methods Enzymol. 235:295-304.

Mercante, J., Suzuki, K., Cheng, X., Babitzke, P., and Romeo, T. 2006. Comprehensive alanine-scanning mutagenesis of Escherichia coli CsrA defines two subdomains of critical functional importance. J. Biol. Chem. 281:31832-31842.

Miller, J. H. 1972. Experiments in Molecular Genetics. Cold Spring Harbor Laboratory, New York.

Moll, S., Schneider, D. J., Stodghill, P., Myers, C. R., Cartinhour, S. W., and Filiatrault, M. J. 2010. Construction of an $r \operatorname{smX}$ co-variance model and identification of five $r s m X$ non-coding RNAs in Pseudomonas syringae pv. tomato DC3000. RNA Biol. 7:508-516.

Morris, E. R., Hall, G., Li, C., Heeb, S., Kulkarni, R. V., Lovelock, L., Silistre, H., Messina, M., Cámara, M., Emsley, J., Williams, P., and Searle, M. S. 2013. Structural rearrangement in an RsmA/CsrA ortholog of Pseudomonas aeruginosa creates a dimeric RNA-binding protein, RsmN. Structure 21:1659-1671.

Mulet, M., Lalucat, J., and García-Valdés, E. 2010. DNA sequence-based analysis of the Pseudomonas species. Environ. Microbiol. 12:1513-1530.

Navazo, A., Barahona, E., Redondo-Nieto, M., Martínez-Granero, F., Rivilla, R., and Martín, M. 2009. Three independent signalling pathways repress motility in Pseudomonas fluorescens F113. Microb. Biotechnol. 2:489-498.

Nogales, J., Vargas, P., Farias, G. A., Olmedilla, A., Sanjuán, J., and Gallegos, M. T. 2015. FleQ coordinates flagellum-dependent and -independent motilities in Pseudomonas syringae pv. tomato DC3000. Appl. Environ. Microbiol. 81:7533-7545.

Ortiz-Martín, I., Thwaites, R., Mansfield, J. W., and Beuzón, C. R. 2010. Negative regulation of the Hrp type III secretion system in Pseudomonas syringae pv. phaseolicola. Mol. Plant-Microbe Interact. 23:682-701.
Pérez-Mendoza, D., Aragón, I. M., Prada-Ramírez, H. A., RomeroJiménez, L., Ramos, C., Gallegos, M. T., and Sanjuán, J. 2014 Responses to elevated c-di-GMP levels in mutualistic and pathogenic plant-interacting bacteria. PLoS One 9:e91645.

Pessi, G., Williams, F., Hindle, Z., Heurlier, K., Holden, M. T., Cámara, M., Haas, D., and Williams, P. 2001. The global posttranscriptional regulator RsmA modulates production of virulence determinants and $\mathrm{N}$-acylhomoserine lactones in Pseudomonas aeruginosa. J. Bacteriol. 183:6676-6683.

Prada-Ramírez, H. A., Pérez-Mendoza, D., Felipe, A., Martínez-Granero, F., Rivilla, R., Sanjuán, J., and Gallegos, M. T. 2016. AmrZ regulates cellulose production in Pseudomonas syringae pv. tomato DC3000. Mol. Microbiol. 99:960-977.

Ramette, A., Frapolli, M., Fischer-Le Saux, M., Gruffaz, C., Meyer, J. M., Défago, G., Sutra, L., and Moënne-Loccoz, Y. 2011. Pseudomonas protegens sp. nov., widespread plant-protecting bacteria producing the biocontrol compounds 2,4-diacetylphloroglucinol and pyoluteorin. Syst. Appl. Microbiol. 34:180-188.

Reimmann, C., Valverde, C., Kay, E., and Haas, D. 2005. Posttranscriptional repression of $\mathrm{GacS} / \mathrm{GacA}$-controlled genes by the RNA-binding protein RsmE acting together with RsmA in the biocontrol strain Pseudomonas fluorescens CHA0. J. Bacteriol. 187:276-285.

Robertsen, B. K., Aman, P., Darvill, A. G., McNeil, M., and Albersheim, P. 1981. Host-symbiont interactions: V. The structure of acidic extracellular polysaccaharides secreted by Rhizobium leguminosarum and Rhizobium trifolii. Plant Physiol. 67:389-400.

Roine, E., Wei, W., Yuan, J., Nurmiaho-Lassila, E. L., Kalkkinen, N., Romantschuk, M., and He, S. Y. 1997. Hrp pilus: An hrp-dependent bacterial surface appendage produced by Pseudomonas syringae pv. tomato DC3000. Proc. Natl. Acad. Sci. U.S.A. 94:3459-3464.

Romeo, T., Gong, M., Liu, M. Y., and Brun-Zinkernagel, A. M. 1993. Identification and molecular characterization of $c s r A$, a pleiotropic gene from Escherichia coli that affects glycogen biosynthesis, gluconeogenesis, cell size, and surface properties. J. Bacteriol. 175:4744-4755.

Rumbaugh, K. P. 2014. Genomic complexity and plasticity ensure Pseudomonas success. FEMS Microbiol. Lett. 356:141-143.

Sambrook, J., Fritsch, E. F., and Maniatis, T. 1989. Molecular Cloning: A Laboratory Manual. Cold Spring Harbor Laboratory Press, New York.

Schubert, M., Lapouge, K., Duss, O., Oberstrass, F. C., Jelesarov, I., Haas, D., and Allain, F. H. 2007. Molecular basis of messenger RNA recognition by the specific bacterial repressing clamp RsmA/CsrA. Nat. Struct. Mol. Biol. 14:807-813.

Song, C., van der Voort, M., van de Mortel, J., Hassan, K. A., Elbourne, L. D., Paulsen, I. T., Loper, J. E., and Raaijmakers, J. M. 2014. The Rsm regulon of plant growth-promoting Pseudomonas fluorescens SS101: Role of small RNAs in regulation of lipopeptide biosynthesis. Microb. Biotechnol. 8:296-310.

Sonnleitner, E., Abdou, L., and Haas, D. 2009. Small RNA as global regulator of carbon catabolite repression in Pseudomonas aeruginosa. Proc. Natl. Acad. Sci. U.S.A. 106:21866-21871.

Taira, S., Tuimala, J., Roine, E., Nurmiaho-Lassila, E. L., Savilahti, H., and Romantschuk, M. 1999. Mutational analysis of the Pseudomonas syringae pv. tomato hrpA gene encoding Hrp pilus subunit. Mol. Microbiol. 34: 737-744.

Vakulskas, C. A., Potts, A. H., Babitzke, P., Ahmer, B. M., and Romeo, T. 2015. Regulation of bacterial virulence by Csr (Rsm) systems. Microbiol. Mol. Biol. Rev. 79:193-224.

Vallet-Gely, I., Novikov, A., Augusto, L., Liehl, P., Bolbach, G., PéchyTarr, M., Cosson, P., Keel, C., Caroff, M., and Lemaitre, B. 2010. Association of hemolytic activity of Pseudomonas entomophila, a versatile soil bacterium, with cyclic lipopeptide production. Appl. Environ. Microbiol. 76:910-921.

Valverde, C., and Haas, D. 2008. Small RNAs controlled by two-component systems. Adv. Exp. Med. Biol. 631:54-79.

Valverde, C., Heeb, S., Keel, C., and Haas, D. 2003. RsmY, a small regulatory RNA, is required in concert with RsmZ for GacA-dependent expression of biocontrol traits in Pseudomonas fluorescens CHA0. Mol. Microbiol. 50:1361-1379.

Vargas, P., Farias, G. A., Nogales, J., Prada, H., Carvajal, V., Barón, M., Rivilla, R., Martín, M., Olmedilla, A., and Gallegos, M. T. 2013. Plant flavonoids target Pseudomonas syringae pv. tomato DC3000 flagella and type III secretion system. Environ. Microbiol. Rep. 5:841-850.

Willis, D. K., Holmstadt, J. J., and Kinscherf, T. G. 2001. Genetic evidence that loss of virulence associated with gacS or gacA mutations in Pseudomonas syringae B728a does not result from effects on alginate production. Appl. Environ. Microbiol. 67:1400-1403.

Willis, D. K., Hrabak, E. M., Rich, J. J., Barta, T. M., Lindow, S. E., and Panopoulos, N. J. 1990. Isolation and characterization of a Pseudomonas syringae pv. syringae mutant deficient in lesion formation on bean. Mol. Plant-Microbe Interact. 3:149-156. 